\title{
Novel antiviral activity of mung bean sprouts against respiratory syncytial virus and herpes simplex virus -1: an in vitro study on virally infected Vero and MRC-5 cell lines
}

Rand R Hafidh ${ }^{1,2}$, Ahmed S Abdulamir ${ }^{3 *}$, Fatimah Abu Bakar ${ }^{4^{*}}$, Zamberi Sekawi ${ }^{5}$, Fatemeh Jahansheri ${ }^{5}$ and Farid Azizi Jalilian ${ }^{6}$

\begin{abstract}
Background: New sources for discovering novel antiviral agents are desperately needed. The current antiviral products are both expensive and not very effective.

Methods: The antiviral activity of methanol extract of mung bean sprouts (MBS), compared to Ribavarin and Acyclovir, on respiratory syncytial virus (RSV) and Herpes Simplex virus -1 (HSV-1) was investigated using cytotoxicity, virus yield reduction, virucidal activity, and prophylactic activity assays on Vero and MRC-5 cell lines. Moreover, the level of antiviral cytokines, IFNB, TNFa, IL-1, and IL-6 was assessed in MBS-treated, virally infected, virally infected MBS-treated, and control groups of MRC-5 cells using ELISA.
\end{abstract}

Results: MBS extract showed reduction factors (RF) $2.2 \times 10$ and $0.5 \times 10^{2}$ for RSV and HSV-1, respectively. The $2 \mathrm{~h}$ incubation virucidal and prophylactic selectivity indices (SI) of MBS on RSV were 14.18 and 12.82 versus Ribavarin SI of 23.39 and 21.95, respectively, and on HSV-1, SI were 18.23 and 10.9 versus Acyclovir, 22.56 and 15.04, respectively. All SI values were $>10$ indicating that MBS has a good direct antiviral and prophylactic activities on both RSV and HSV-1. Moreover, interestingly, MBS extract induced vigorously IFN $\beta$, TNFa, IL-1, and IL-6 cytokines in MRC-5 infected-treated group far more than other groups $(P<0.05)$ and induced TNFa and IL-6 in treated group more than infected group $(P<0.05)$.

Conclusions: MBS extract has potent antiviral and to a lesser extent, prophylactic activities against both RSV and HSV-1, and in case of HSV-1, these activities were comparable to Acyclovir. Part of the underlying mechanism(s) of these activities is attributed to MBS potential to remarkably induce antiviral cytokines in human cells. Hence, we infer that MBS methanol extract could be used as such or as purified active component in protecting and treating RSV and HSV-1 infections. More studies are needed to pinpoint the exact active components responsible for the MBS antiviral activities.

Keywords: Mung bean sprout, Respiratory syncytial virus, Herpes simplex virus-1, Ribavarin, Acyclovir, Cytotoxicity assay, Interferon, Tumor necrosis factor

\footnotetext{
* Correspondence: ahmsah73@yahoo.com; fatim@upm.edu.my

${ }^{3}$ Department of Microbiology, College of Medicine, Alnahrain University, PO Box 70030, Baghdad, Iraq

${ }^{4}$ Faculty of Food Science and Technology, University Putra Malaysia, Serdang 43400, Selangor, Malaysia

Full list of author information is available at the end of the article
} 


\section{Background}

During the past decade, many potent agents have become available against viral infections; however, the increasing clinical use or the abuse of these agents has been associated with the emergence of dangerous drugresistant viral strains. In addition, the dose-limiting toxic effects of the known antiviral agents have been observed among patients especially immunocompromised individuals [1-3].

Plant bioactive molecules which occur in plants as secondary metabolites have significant defense mechanisms against predation, herbivores, fungal attack, microbial invasion, and viral infections [4]. Therefore, during the recent decade, extracts of plants as phytochemicals, such as phenolic compounds derived from the secondary plant metabolism, are getting more important as potential sources for viral inhibitors. Many studies showed a great range of pharmacological effects of these substances, including vasodilatation, antiallergenic, anti-inflammatory and antiviral properties [5]. More to the point, the relative success of various species of medicinal plant extracts with antiviral properties has raised optimism about the future of phyto-antiviral agents [6].

The discovery of safe and effective antiviral agents from plant extracts may secure humanity from the drug resistant viruses. Therefore, in order to discover new sources of safe antiviral therapies, the objectives of the current study are to investigate whether there is any antiviral activity of mung bean sprout (Vigna radiata $\mathrm{L}$.), or (MBS), methanol crude extract and to assess part of the underlying mechanism of action of the antiviral activity, if any, of this methanol crude extract. Discovering effective antiviral plant extract is important in breaking the long-lasting shortage of antiviral drugs in industry and to boost the safety use of antiviral agents. MBS antiviral activity can be used in the form of extract or by isolating the responsible active component(s).

\section{Results}

To investigate the in vitro antiviral properties of MBS extract, four approaches were performed. These methods included end point titration technique (EPTT), plaque assay, cytopathic reduction assay, and microculture tetrazolium assay (MTT).

\section{Estimating the antiviral activity by virus yield reduction assay}

It has been shown that the virus yield reduction assay is a powerful technique for evaluating the efficacy of potential antiviral compounds [7]. In order to assess the antiviral activity, the maximum nontoxic dose of MBS extract, i.e., IC50 was applied to virus host cells after infection with certain virus in an attempt to measure the reduction of virus titer. The reductions of virus titers (RSV and HSV-1) were determined in term of virus titer $\log$ after treatment in addition to the reduction factor (RF), i.e. the ratio of the virus titer in the absence of the extract over virus titer in the presence of the extract [8].

In this study, MBS extract showed moderate antiviral activity on HSV-1 titration in which HSV-1 titer was reduced by two $\log$ (Table 1). On the other hand, MBS extract showed slight antiviral activity against RSV as RSV virus titer was reduced by one log (Table 1 ). MBS extract showed RF values of $\geq 10$ indicating a pronounced antiviral activities.

\section{The virucidal, or Direct Virus Inactivation (DVI) and the prophylactic, or Inhibition of Virus Replication (IVR) by MBS extract}

The neutralization and the inhibitory effects of MBS extract on virus replication (RSV and HSV-1) were studied. The study included incubation of the extract with virus specific cells (Vero and MRC-5) or with the virus itself. The results were obtained by microscopic examination for virus-induced $\mathrm{CPE}$ and the measurement of optical density by the MTT assay. The results of cytopathic reduction assay were expressed as mean of three independent experiments with five extract concentrations. As demonstrated in (Table 2), only the first concentration $(220.96 \mathrm{mg} / \mathrm{ml})$ of MBS extract inhibited the RSV-induced CPE completely at different incubation times while $25 \%$ CPE started to develop at the concentration of $110.48 \mathrm{mg} / \mathrm{ml}$ when the virus was mixed with MBS extract and was then applied directly to Vero cells (zero hour time of incubation). The reduction of $50 \%$ RSV-CPE was observed when the virus was incubated for zero hour with $55.24 \mathrm{mg} / \mathrm{ml}$ of MBS and for $1 \mathrm{~h}$ and $2 \mathrm{~h}$ with $27.62 \mathrm{mg} / \mathrm{ml}$ of MBS extract. On the other hand, when the extract was incubated for $30 \mathrm{~min}$ and $1 \mathrm{~h}$ with cells before virus infection $55.24 \mathrm{mg} / \mathrm{ml}$ of MBS extract produced $25 \%$ of RSV-CPE

Table 1 The reduction in the RSV and HSV-1 titers after MBS extract treatment. The virus titer was obtained by EPTT to determine the virus titer in (TCID50/ml)

\begin{tabular}{lllll}
\hline Virus & Virus titer before treatment & Virus titer after treatment & aVirus titer reduction & beduction factor \\
\hline RSV & $3.16 \times 10^{-3}$ & $1.422 \times 10^{-2}$ & 1 log & $2.22 \times 10$ \\
HSV-1 & $5.01 \times 10^{-3}$ & $8.97 \times 10^{-1}$ & $2 \log$ & $0.55 \times 10^{2}$ \\
\hline
\end{tabular}

Note: ${ }^{a}$ Virus titer reduction: the extract is considered active if the virus titer was reduced by 2 log. ${ }^{\mathrm{b}}$ Reduction factor (RF): virus titer in the absence of drug over virus titer in the presence of drug. $\mathrm{RF} \geq 10^{3}$ strong antiviral activity, $\mathrm{RF}=10^{2}$ moderate antiviral activity and $\mathrm{RF}=10^{1}$ slight antiviral activity 
Table 2 RSV-induced CPE (\%) after incubating the MBS extract with the virus and with Vero cell line

\begin{tabular}{lllllll}
\hline Protocols & Time & ${ }^{\mathrm{a} C o n c .1}$ & Conc.2 & Conc.3 & Conc.4 & Conc.5 \\
\hline${ }^{\mathrm{b}} \mathrm{DVI}$ & $0 \mathrm{~h}$ & $0 \%$ & $0-25 \%$ & $25-50 \%$ & $50 \%$ & $75 \%$ \\
& $1 \mathrm{~h}$ & $0 \%$ & $0 \%$ & $0-25 \%$ & $50 \%$ & $50-75 \%$ \\
& $2 \mathrm{~h}$ & $0 \%$ & $0 \%$ & $0 \%$ & $50 \%$ & $75 \%$ \\
${ }^{\mathrm{C}}$ VVR & $30 \mathrm{~min}$ & $0 \%$ & $0 \%$ & $25-50 \%$ & $50 \%$ & $50-75 \%$ \\
& $1 \mathrm{~h}$ & $0 \%$ & $0 \%$ & $0-25 \%$ & $25-50 \%$ & $50-75 \%$ \\
\hline
\end{tabular}

Note: ${ }^{\mathrm{a} C o n c .:}$ extract concentration $(220.96,110.48,55.24,27.62$, and $13.81 \mathrm{mg} / \mathrm{ml})$. ${ }^{b} D V l:$ the direct virus inactivation. 9 IVR: the inhibition in virus infection after specific cell treatment

in Vero cells whereas, 50 \% CPE in Vero cells was observed after $30 \mathrm{~min}$ and $1 \mathrm{~h}$ with concentration $27.62 \mathrm{mg} / \mathrm{ml}$ of MBS extract (Table 2). The Lowest concentration of MBS extract enough to inhibit HSV-1 CPE completely after (zero, 1, and $2 \mathrm{~h}$ ) of incubation with the virus before adding to MRC-5 cells was $136.58 \mathrm{mg} / \mathrm{ml}$. In comparison to the direct effect of MBS extract on RSV, $25 \%$ of HSV-1 CPE was observed with only $68.29 \mathrm{mg} / \mathrm{ml}$ of the extract when mixed together with the virus and applied directly to MRC5 while MBS extract at concentrations 17.07 and $8.53 \mathrm{mg} /$ $\mathrm{ml}$ were capable to inhibit $50 \% \mathrm{CPE}$ after 1 and $2 \mathrm{~h}$ of incubation with the virus. The indirect effect of MBS extract, which was estimated by incubating the extract with MRC-5 cells, was clearly different from the same effect on Vero cells. Here, the extract needed only the concentration of $(17.07 \mathrm{mg} / \mathrm{ml})$ to reduce the CPE to $50 \%$ after $30 \mathrm{~min}$ and $1 \mathrm{~h}$ of incubation with the cells (Table 3 ).

MBS extract at concentration of $220.96 \mathrm{mg} / \mathrm{ml}$ caused $50 \%$ cytotoxicity (CC50) on Vero cells (specific cells for RSV) while only $136.58 \mathrm{mg} / \mathrm{ml}$ was enough to cause the $50 \%$ death (CC50) in MRC-5 cell line (specific cells for HSV-1). The significant direct antiviral activity of MBS extract on RSV was observed when the extract incubated with the virus for $1 \mathrm{~h}$ then applied to Vero cells (IC50 = $15.62 \mathrm{mg} / \mathrm{ml}$ ) in comparison to zero hour and $2 \mathrm{~h}$ of incubation which were found to be less active $(P<0.05)$. These significant findings were supported by the results of the SI, 14.18, for $1 \mathrm{~h}$ incubation time which was significantly higher than that of zero hour, 8.35, and $2 \mathrm{~h}$, $8.28(P<0.05)$. These results supported our findings

Table 3 HSV-1 induced CPE (\%) after incubating the MBS extract with the virus and with MRC-5 cell line

\begin{tabular}{lllllll}
\hline Protocols & Time & ${ }^{\mathrm{a}}$ Conc. & Conc.2 & Conc.3 & Conc.4 & Conc.5 \\
\hline${ }^{\mathrm{b}} \mathrm{DVI}$ & $0 \mathrm{~h}$ & $0 \%$ & $0-25 \%$ & $25-50 \%$ & $50-75 \%$ & $100 \%$ \\
& $1 \mathrm{~h}$ & $0 \%$ & $0 \%$ & $0-25 \%$ & $25-50 \%$ & $50-75 \%$ \\
& $2 \mathrm{~h}$ & $0 \%$ & $0 \%$ & $0 \%$ & $0-25 \%$ & $50 \%$ \\
${ }^{\mathrm{C}} \mathrm{VRR}$ & $30 \mathrm{~min}$ & $0 \%$ & $0 \%$ & $25-50 \%$ & $50 \%$ & $\geq 75 \%$ \\
& $1 \mathrm{~h}$ & $0 \%$ & $0 \%$ & $0-25 \%$ & $25-50 \%$ & $50-75 \%$ \\
\hline
\end{tabular}

Note: ${ }^{a}$ Conc.: extract concentration $(136.58,68.29,34.14,17.07$, and $8.53 \mathrm{mg} / \mathrm{ml})$. ${ }^{b} D V$ : the direct virus inactivation. IVR: the inhibition in virus infection after specific cell treatment regarding the efficacy of $1 \mathrm{~h}$ incubation of virus with MBS. Regarding the incubation of MBS extract with Vero cells before the infection with RSV, the incubation time of one hour was also the proper time to inhibit $50 \%$ of RSV-induced CPE (IC50 = $17.23 \mathrm{mg} / \mathrm{ml})$ which gave SI of 12.82 when compared with $30 \mathrm{~min}$ of incubation. Therefore, $1 \mathrm{~h}$ time of incubation was found to be the proper time for both direct virucidal effect of MBS and indirect inhibition of virus replication by treating Vero cells with MBS. This incubation time was used to investigate the antiviral effect of the standard drug (Ribavirin) and compare it with MBS extract activity (Tables 4, 5 and 6). On the other hand, when incubating HSV-1 with MBS extract, it needed $2 \mathrm{~h}$ to inhibit $50 \%$ of its CPE on MRC-5 cells (IC50 = $7.62 \mathrm{mg} / \mathrm{ml}$ ) which was higher than that of zero or $1 \mathrm{~h}$ incubation times $(P<0.05)$. The SI, 18.23 for $2 \mathrm{~h}$ reflected the same result when compared to the SI of zero hour and $1 \mathrm{~h}, 5.69$ and 9.91, respectively $(P<0.05)$. Two hours incubation was used to estimate the antiviral activity of the standard drug (Acyclovir) in order to be compared with that of MBS extract. MBS extract needed $1 \mathrm{~h}$ incubation time to induce its prophylactic effect against $\mathrm{HSV}-1$ when incubated with MRC-5. It needed $1 \mathrm{~h}$ to give IC50 of $12.72 \mathrm{mg} / \mathrm{ml}$ and resulted in SI of 10.9. This effective time of incubation, i.e., $1 \mathrm{~h}$ to provide the prophylactic effect of MBS extract was used to evaluate the same activity for Acyclovir. These results reflected the fact that the direct effect of MBS extract needed more time (about $2 \mathrm{~h}$ ) to create effective SI against HSV-1 while it needed only $1 \mathrm{~h}$ to generate such effective SI against RSV (Tables 7, 8 and 9).

\section{Comparison between the virucidal and the prophylactic properties of MBS extract to RSV, and between that of MBS extract and Ribavirin}

The proper incubation time of each protocol for MBS extract is compared together to find the best antiviral activity. MBS extract was effective as both prophylactic

Table 4 The antiviral activity of MBS extract on RSV by the direct virucidal effect and the prophylactic effect on Vero cell line

\begin{tabular}{lllll}
\hline Protocol & Time & ${ }^{\mathrm{a}} \mathrm{CC} 50 \mathrm{mg} / \mathrm{ml}$ & ${ }^{\mathrm{b}} \mathrm{C} 50 \mathrm{mg} / \mathrm{ml}$ & ${ }^{\mathrm{c}} \mathrm{SI}$ \\
\hline${ }^{\mathrm{d} D V I}$ & $0 \mathrm{~h}$ & $220.96 \pm 60.56$ & $26.98 \pm 2.82$ & $8.35 \pm 0.79$ \\
& $1 \mathrm{~h}$ & $220.96 \pm 60.56$ & $15.62 \pm 0.61$ & $14.18 \pm 0.54$ \\
& $2 \mathrm{~h}$ & $220.96 \pm 60.56$ & $26.72 \pm 0.95$ & $8.28 \pm 0.29$ \\
Ribavirin & $1 \mathrm{~h}$ & $1.4 \pm 0.088$ & $0.06 \pm 0.005$ & $23.39 \pm 2.44$ \\
${ }^{\mathrm{e}} \mathrm{IVR}$ & $30 \mathrm{~min}$ & $220.96 \pm 60.56$ & $18.92 \pm 0.47$ & $11.69 \pm 0.28$ \\
& $1 \mathrm{~h}$ & $220.96 \pm 60.56$ & $17.23 \pm 0.3$ & $12.82 \pm 0.23$ \\
Ribavirin & $1 \mathrm{~h}$ & $2.28 \pm 0.057$ & $0.087 \pm 0.005$ & $21.95 \pm 2.12$ \\
\hline
\end{tabular}

Note: ${ }^{\mathrm{a}}$ cytotoxic concentration $50{ }^{\mathrm{b}}$ Inhibitory concentration $50,{ }^{\mathrm{c}}$ selective index ${ }^{\mathrm{d}} \mathrm{DV}$ : the direct virus inactivation. ${ }^{\mathrm{e} I V R}$ : the inhibition in virus infection after specific cell treatment 
Table 5 The differences in $50 \%$ inhibitory concentration (IC50) of MBS extract on RSV between the different times in the same protocol (DVI and IVR)

\begin{tabular}{lllll}
\hline Protocol & Time vs Time & IC50 vs IC50 & $P$ value \\
\hline${ }^{\mathrm{D} D V I}$ & O h vs $1 \mathrm{~h}$ & $26.98 \pm 2.82$ vs $15.62 \pm 0.61$ & 0.008 & Significant \\
& 0 h vs $2 \mathrm{~h}$ & $26.98 \pm 2.82$ vs $26.72 \pm 0.95$ & 0.46 & Non-Significant \\
& $1 \mathrm{~h}$ vs $2 \mathrm{~h}$ & $15.62 \pm 0.61$ vs $26.72 \pm 0.95$ & 0.0003 & Significant \\
${ }^{\text {bIVR }}$ & 30 min vs $1 \mathrm{~h}$ & $18.92 \pm 0.47$ vs $17.23 \pm 0.3$ & 0.02 & Significant \\
\hline
\end{tabular}

Note: ${ }^{\mathrm{a} D V I}$ : the direct virus inactivation. ${ }^{\mathrm{b}}$ IVR: the inhibition in virus infection after specific cell treatment

and virucidal agent; however, it was a bit better as a virucidal agent on RSV with (IC50 = $15.62 \mathrm{mg} / \mathrm{ml})$ than as prophylactic agent. This was shown by SI values which were 14.18 and 12.82 for virucidal and prophylactic activities, respectively (Tables 10 and 11).

Comparing with the anti-RSV activity of Ribavirin, there were significant differences in the prophylactic and virucidal effects of MBS extract and Ribavirin $(P<0.05)$ at the same time of incubation. The results revealed that the SI of MBS extract as prophylactic agent $(\mathrm{SI}=12.82)$ was less than that of Ribavirin ( $\mathrm{SI}=$ 21.95). Furthermore, the level of MBS extract as a virucidal agent $(\mathrm{SI}=14.18)$ was lower than that of Ribavirin $(\mathrm{SI}=23.39)$, (Table 11).

\section{Comparison between the virucidal and the prophylactic properties of MBS extract to HSV-1, and between that of MBS extract and Acyclovir}

By using the best incubation time that generated a significant antiviral activity against HSV-1, the prophylactic and virucidal effects of MBS extract were compared together. At time of incubation ( $2 \mathrm{~h}$ ), MBS extract was effective as virucidal and prophylactic agent but it was most prominent as a virucidal agent against HSV-1 using $7.62 \mathrm{mg} / \mathrm{ml} \mathrm{MBS}$ extract (Table 12). As shown in (Table 12), there were significant differences $(P<0.05)$ when comparing the SI values between different protocols for MBS extract. In other words, the SI value, 18.23, of the virucidal activity of MBS extract was significantly higher than that of the prophylactic action.

In addition, MBS extract did not show any significant difference when its prophylactic and virucidal activities were compared with that of Acyclovir $(P>0.05)$, (Table 13).

\section{The antiviral cytokines produced by the treated-viral infected cells}

The extracellular concentration of a group of cytokines implicated in the antiviral response was monitored in the supernatant of MRC-5 cells. The cells were categorized into four groups. The first group was MRC-5 cells cultured without exposure to either extract or viral infection by HSV-1. The second group was MRC-5 cells treated for one hour with IC50 of IVR protocol of MBS extract alone. The third group was MRC-5 cells infected with HSV-1. The fourth group was MRC-5 cells pretreated with IC50 of IVR protocol of MBS extract and cells were then infected with HSV-1. Both the group of MBS treated cells and the group of infected cells showed higher synthesis of all tested cytokines, IFN $\beta$, IL-1, IL-6, and TNF $\alpha$ than in control cells (MBS treated cells: $P=0.005,0.011,<0.001,<0.001$; infected cells: $P=0.009,0.006,0.041,0.01$, respectively). Moreover, the level of IFN $\beta$ and IL- 1 was not significantly different between MBS treated cells and infected cells $(P=0.75,0.31$, respectively) while the level of IL-6 and TNF $\alpha$ was higher in MBS treated cells than in infected cells $(P=0.009,0.025$, respectively). These results indicated that MBS extract can induce the synthesis of IL- 6 and TNF $\alpha$ more strongly than the synthesis of IFN $\beta$ and IL-1 $(P<0.05)$, (Table 14 and Fig. 1). Above all, MBS extract induced synthesis of all tested cytokines in MRC-5 cells infected with HSV-1 far higher than all other groups $(P<0.001)$, (Table 14 and Fig. 1). Moreover, MBS extract showed a powerful prophylactic effect for MRC-5 cells against viral infection by charging the MBS treated cells to be ready and highly responsive against any viral infection.

Table 6 The differences in selectivity index (SI) of MBS extract on RSV between the different times in the same protocol (DVI and IVR)

\begin{tabular}{|c|c|c|c|c|}
\hline Protocol & Time vs Time & SI vs SI & $P$ value & \\
\hline \multirow[t]{3}{*}{${ }^{\mathrm{a} D V I}$} & Oh vs $1 \mathrm{~h}$ & $8.35 \pm 0.79$ vs $14.18 \pm 0.54$ & 0.001 & Significant \\
\hline & $0 \mathrm{~h}$ vs $2 \mathrm{~h}$ & $8.35 \pm 0.79$ vs $8.28 \pm 0.29$ & 0.47 & Non-Significant \\
\hline & $1 \mathrm{~h}$ vs $2 \mathrm{~h}$ & $14.18 \pm 0.54$ vs $8.28 \pm 0.29$ & 0.0003 & Significant \\
\hline${ }^{b} I V R$ & $30 \mathrm{~min}$ vs $1 \mathrm{~h}$ & $11.69 \pm 0.28$ vs $12.82 \pm 0.23$ & 0.018 & Significant \\
\hline
\end{tabular}

Note: ${ }^{\mathrm{a} D V I}$ : the direct virus inactivation. ${ }^{\mathrm{b}}$ IVR: the inhibition in virus infection after specific cell treatment 
Table 7 The antiviral activity of MBS extract on HSV-1 by the direct virucidal effect and the prophylactic effect on MRC-5 cell line

\begin{tabular}{lllll}
\hline Protocol & Time & ${ }^{\mathrm{a} C C 50 \mathrm{mg} / \mathrm{ml}}$ & ${ }^{\mathrm{b}}$ IC50 mg/ml & ${ }^{\mathrm{C}} \mathrm{SI}$ \\
\hline${ }^{\mathrm{d} D V I}$ & $0 \mathrm{~h}$ & $136.58 \pm 55.08$ & $24.17 \pm 1.43$ & $5.69 \pm 0.35$ \\
& $1 \mathrm{~h}$ & $136.58 \pm 55.08$ & $13.8 \pm 0.44$ & $9.91 \pm 0.31$ \\
& $2 \mathrm{~h}$ & $136.58 \pm 55.08$ & $7.62 \pm 0.71$ & $18.23 \pm 1.69$ \\
Acyclovir & $2 \mathrm{~h}$ & $0.35 \pm 0.005$ & $0.014 \pm 0.0005$ & $22.56 \pm 1.11$ \\
e IVR & $30 \mathrm{~min}$ & $136.58 \pm 55.08$ & $15.53 \pm 0.74$ & $8.83 \pm 0.42$ \\
& $1 \mathrm{~h}$ & $136.58 \pm 55.08$ & $12.72 \pm 1.12$ & $10.9 \pm 0.96$ \\
Acyclovir & $1 \mathrm{~h}$ & $0.37 \pm 0.005$ & $0.02 \pm 0.003$ & $15.04 \pm 1.9$
\end{tabular}

Note: a cytotoxic concentration 50 , b Inhibitory concentration 50 , c selective index ${ }^{\mathrm{d}} \mathrm{DV}$ : the direct virus inactivation. ${ }^{\mathrm{e}}$ IVR: the inhibition in virus infection after specific cell treatment

\section{Discussion}

Flavonoids, the most common polyphenols found in plants, have been associated with biological effects such as antibacterial, antiviral, anti-inflammatory, antiplatelet, antioxidant, free radical scavenging, and vasodilatory effects $[9,10]$. MBS is known to have high antioxidant activity which may be correlated with an effective antiviral activity.

To establish the efficacy of the antiviral activity of MBS extract, virus yield reduction assay was performed in which plant extract was added to host cells (Vero and MRC-5) after infection with RSV and HSV-1, respectively. The maximum non-cytotoxic concentration of MBS extract was able to reduce HSV-1 by $2 \log \left(\mathrm{RF}=0.55 \times 10^{2}\right)$ and RSV only by $1 \log (\mathrm{RF}=2.22 \times 10)$ to give a moderate and slight antiviral activity against HSV-1 and RSV, respectively. These results reflected the efficacy of the solvent, i.e., methanol, in extracting the antiviral components from MBS. Moreover, the synergistic effect of these extracted polyphenols may play a critical role in this activity. It was reported that methanol is the best solvent for the consistent extraction of antimicrobial substances from medicinal plants compared to other solvents such as water, ethanol, or hexane [11]. The benefit of crude extract over the fractionated extract is that the crude one is composed of a large mixture of polyphenols that could interplay effectively giving rise to novel and antiviral activities. It was stated that different polyphenolic components of a plant extract may influence different steps of antimicrobial activity in a synergistic manner [12].

MBS extract reduced virus titer in one to two logs. Plant extracts are considered active if the virus titer was reduced by one log and highly active by two logs after treatment [7, 13]. Furthermore, any extract with RF value of $\geq 10$ should be considered highly valuable and selected to determine the mode of its antiviral action [14]. For these reasons, MBS extract was further analyzed to investigate its antiviral activities as well as their modes of action to reduce RSV and HSV-1 titer.

The results showed that the antiviral activity of MBS extract is dose-dependent. Concentrations of extract close to the CC50 caused $100 \%$ inhibition of CPE. However, much lower concentrations succeeded in reducing virus CPE in large extent giving clue on the potent antiviral activity in MBS extract. MBS extract at concentration of $220.96 \mathrm{mg} / \mathrm{ml}$ caused death to $50 \%$ of Vero cells and at $136.58 \mathrm{mg} / \mathrm{ml}$ caused death in $50 \%$ of MRC-5 cells. Therefore, CC50 values of MBS extract on both Vero and MRC-5 cells are considered too high when compared to the concentrations yielded $50 \%$ antiviral activity, IC50, which ranged from 7.62 to 15.62 . These figures of IC50 indicated high selectivity in the extract activity. To elucidate this aspect, it was necessary to calculate the selectivity index, i.e., the therapeutic index. It is generally considered that biological efficacy is not due to in vitro cytotoxicity when $\mathrm{SI} \geq 10[15,16]$.

The results of MBS extract cytotoxicity on the virus host cells (Vero and MRC-5 cells) were in correlation with the effective concentration which was needed to inhibit virus-induced CPE. The study's results found that MBS extract was needed in lower concentrations to inhibit HSV-1 induced CPE than that needed to inhibit RSV-induced CPE. This depended on the CC50 values of MBS extract on MRC-5 and Vero cells. The results disclosed the fact that MBS extract was more cytotoxic to $\mathrm{MRC}-5$ cells $(\mathrm{CC} 50=136.58 \mathrm{mg} / \mathrm{ml})$ than to Vero cells $(\mathrm{CC} 50=220.96 \mathrm{mg} / \mathrm{ml})$. In other words, Vero cells can tolerate higher MBS extract concentrations than can MRC-5 cells. Fortunately, the high cytotoxicity of MBS extract against MRC-5 was accompanied with high antiviral activity against HSV-1 leading to attain low working antiviral concentrations much lower than the

Table 8 The differences in the 50 \% inhibitory concentration (IC50) of MBS extract on HSV-1 between the different times in the same protocol (DVI and IVR)

\begin{tabular}{lllll}
\hline Protocol & Time vs Time & IC50 vs IC50 & $P$ value \\
\hline${ }^{\circ} \mathrm{DVI}$ & $0 \mathrm{~h}$ vs $1 \mathrm{~h}$ & $24.17 \pm 1.43$ vs $13.8 \pm 0.44$ & 0.001 & Significant \\
& 0 h vs $2 \mathrm{~h}$ & $24.17 \pm 1.43$ vs $7.62 \pm 0.71$ & 0.0002 & Significant \\
& $1 \mathrm{~h}$ vs $2 \mathrm{~h}$ & $13.8 \pm 0.44$ vs $7.62 \pm 0.71$ & 0.0009 & Significant \\
${ }^{\mathrm{b} I V R}$ & 30 min vs $1 \mathrm{~h}$ & $15.53 \pm 0.74$ vs $12.72 \pm 1.12$ & 0.05 & Non-Significant \\
\hline
\end{tabular}

Note: ${ }^{\mathrm{a} D V I}$ : the direct virus inactivation. ${ }^{\mathrm{b}}$ IVR: the inhibition in virus infection after specific cell treatment 
Table 9 The differences in selectivity index (SI) of MBS extract on HSV-1 between the different times in the same protocol (DVI and IVR)

\begin{tabular}{lllll}
\hline Protocol & Time vs Time & SI vs SI & $P$ value \\
\hline${ }^{\mathrm{a} D V I}$ & $0 \mathrm{~h}$ vs $1 \mathrm{~h}$ & $5.69 \pm 0.35$ vs $9.91 \pm 0.31$ & 0.0004 & Significant \\
& $0 \mathrm{~h}$ vs $2 \mathrm{~h}$ & $5.69 \pm 0.35$ vs $18.23 \pm 1.69$ & 0.0009 & Significant \\
& $1 \mathrm{~h}$ vs $2 \mathrm{~h}$ & $9.91 \pm 0.31$ vs $18.23 \pm 1.69$ & 0.004 & Significant \\
${ }^{\mathrm{b} I V R}$ & 30 min vs $1 \mathrm{~h}$ & $8.83 \pm 0.42$ vs $10.9 \pm 0.96$ & 0.06 & Non-Significant \\
\hline
\end{tabular}

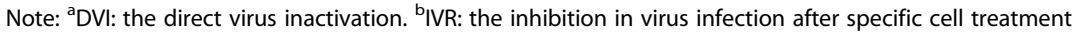

cytotoxic concentrations for the host cells. The maximum non-cytotoxic concentrations (CC50) of MBS extract for both Vero and MRC-5 cells showed significant reduction of RSV- and HSV-1- induced CPE by $100 \%$. This can be attributed to the cytotoxicity of the extract used for the host cells; however, the lower 2-fold concentration of the MBS extract showed the same $100 \%$ inhibition of viral CPE for treatments $1 \mathrm{~h}$ and $2 \mathrm{~h}$. This indicated a specific antiviral activity rather than viral reduction due to cytotoxicity of host cells.

The IVR treatments by MBS extract showed optimal time of $1 \mathrm{~h}$ rather than $30 \mathrm{~min}$ for both Vero and MRC-5 cells while in DVI treatments, $1 \mathrm{~h}$ and $2 \mathrm{~h}$ were optimal for RSV and HSV-1, respectively. Accordingly, $2 \mathrm{~h}$ were enough for HSV-1 while just $1 \mathrm{~h}$ was enough for RSV. This provided evidence that HSV-1 needs longer exposures than RSV with antiviral agents to respond efficiently.

The SI of MBS extract after $1 \mathrm{~h}$ of incubation was quite high (14.18), pointing out to a high selectivity in the extract action. Accordingly, $1 \mathrm{~h}$ of RSV treatment with MBS extract was the proper time to inhibit virusinduced CPE by $50 \%$ with much lower cytotoxicity on the host cells (Vero cells) and significant selectivity on the virus. In addition, the SI of MBS extract treatment for Vero cells before being infected with RSV, namely, IVR protocol, was (12.82), which indicated also a high selectivity in the extract action over the cytotoxicity to Vero cells. The activity of MBS extract on RSV in this study may agree with a previous study which found that the methanol crude extract of some plants is highly effective to inhibit RSV and can be considered the best choice in searching for novel antiviral agents for RSV [17].

The selectivity, SI, of $2 \mathrm{~h}$ treatment of MBS extract for HSV-1 was very high (18.23) while SI for $1 \mathrm{~h}$ treatment, via IVR, of MBS extract to the host cells (MRC- 5 cells) before being infected with HSV-1 was just acceptable, 10.9. The antiviral activities of MBS extract in both DVI and IVR for RSV in Vero cells and HSV-1 in MRC-5 cells gave many indications. First, MBS extract acted as a potent antiviral agent and its action was not related to the cytotoxicity of host cells. Second, MBS extract was highly selective against RSV and HSV-1 or against the virally infected cells. Third, MBS extract, acted as virucidal agent more than prophylactic agent. These valuable results of MBS extract anti-HSV1 activity may be supported by a recent study on plant methanol crude extract which found that such extract found to be effective to inhibit HSV-1 infection in vitro [18]. The results of MBS extract, IC50 and SI, with different modes of action against RSV were significantly better in its virucidal action $(\mathrm{IC} 50=15.62$ and $\mathrm{SI}=14.18)$ than its prophylactic action (IC50 $=17.23$ and SI $=12.82$ ). Similarly, MBS extract was a virucidal agent $(\mathrm{IC50}=7.62$ and $\mathrm{SI}=18.23$ ) rather than a prophylactic agent $(\mathrm{IC} 50=12.72$ and $\mathrm{SI}=$ 10.9) against HSV-1. These findings may point out to the importance of MBS extract as an agent with the ability to interact with viral envelope more sufficiently than its ability to interact with host cell surface. One of the clear reasons that may explain the effective antiviral activity of MBS extract in the current study is the presence of high level of antioxidant compounds in the germinated mung bean sprout. Germination of the mung bean causes a rise in total content of the antioxidant components like phenolic compounds, $\alpha$-tocopherol and vitamin C $[19,20]$. It is well known that $\alpha$-tocopherol, a member of vitamin $\mathrm{E}$ family, has a potent antioxidant activity [21, 22]. Moreover, many studies proved the efficacy of $\alpha$-tocopherol as antithrombotic, anticoagulant, neuroprotective, antiproliferative, immunomodulatory, cell membrane-stabilizing and antiviral [23-25]. On the other hand, ascorbate (Vitamin $C$ ) has been shown to have specific antiviral effect in which it inactivates RNA or DNA of viruses [26-28]. Moreover, ascorbate was found to be able to act synergistically with other phenolic compounds to enhance their antiviral activity [29]. All these facts may explain the effective antiviral activity of MBS extract. The ability of each antioxidant compound to work alone or with other compounds to enhance its

Table 10 Comparisons of the $50 \%$ inhibitory concentration (IC50) of MBS extract on RSV at the best time for each protocol

\begin{tabular}{lllll}
\hline Protocol vs Protocol & Time vs Time & IC50 vs IC50 mg/ml & $P$ value \\
\hline${ }^{a}$ IVR vs ${ }^{b} \mathrm{DVI}$ & $1 \mathrm{~h}$ vs $1 \mathrm{~h}$ & $17.23 \pm 0.3 \mathrm{vs} 15.62 \pm 0.61$ & 0.03 & Significant \\
\hline
\end{tabular}

Note: ${ }^{a}$ IVR: the inhibition in virus infection after specific cell treatment. ${ }^{\mathrm{b}} \mathrm{DVI}$ : the direct virus inactivation 
Table 11 Comparisons of the selectivity index (SI) of antiviral activity on RSV between prophylactic (IVR) and virucidal (DVI) at best time for MBS extract and between that of MBS extract and the standard drug (Ribavirin)

\begin{tabular}{|c|c|c|c|c|c|}
\hline Extract & Protocol vs Protocol & Time vs Time & SI vs SI & $P$ value & \\
\hline MBS & ${ }^{\mathrm{a}} \mathrm{IVR}$ vs ${ }^{\mathrm{b}} \mathrm{DVI}$ & $1 \mathrm{~h}$ vs $1 \mathrm{~h}$ & $12.82 \pm 0.23$ vs $14.18 \pm 0.54$ & 0.04 & $\overline{\text { Significant }}$ \\
\hline MBS vs Ribavirin & ${ }^{\mathrm{a}}$ IVR VS ${ }^{\mathrm{a}} \mathrm{IVR}$ & $1 \mathrm{~h}$ vs $1 \mathrm{~h}$ & $12.82 \pm 0.23$ vs $21.95 \pm 2.12$ & 0.006 & Significant \\
\hline MBS vs Ribavirin & ${ }^{\mathrm{b}} \mathrm{DVI}$ VS ${ }^{\mathrm{b}} \mathrm{DVI}$ & $1 \mathrm{~h}$ vs $1 \mathrm{~h}$ & $14.18 \pm 0.54$ vs $23.39 \pm 2.44$ & 0.01 & Significant \\
\hline
\end{tabular}

Note: ${ }^{a}$ IVR: the inhibition in virus infection after specific cell treatment. ${ }^{\mathrm{b}} \mathrm{DVI}$ : the direct virus inactivation

effect in the antiviral activity was well proven by some studies $[23,24,26]$. These studies suggested that the potent antioxidant activity that leads to antimicrobial activity is a result of a combination of different compounds having synergistic effect [30].

The acute respiratory illness due to RSV is one of the most common causes of hospitalization in very young children worldwide and treatment remains supportive. Ribavirin is approved for the treatment of severe RSV disease; however, its effectiveness in improving outcomes is questionable [31-33]. Additionally, the clinical treatment with Ribavirin requires high doses with significant side effects including thrombocytosis and severe anemia $[34,35]$. All these factors together raise the critical need for a new, safe, and effective antiviral agent to win the battle against RSV.

Despite the fact that MBS extract worked as a virucidal agent $(\mathrm{SI}=14.18)$ more powerfully than as a prophylactic agent $(\mathrm{SI}=12.82)$ against $\mathrm{RSV}$, this activity was not better than the activity of Ribavirin. Both DVI and IVR antiviral activities of MBS extract showed significant differences from that of Ribavirin. Thus, MBS extract had effective virucidal activity against RSV (SI = 14.18) but it is still not much like the virucidal activity of Ribavirin $(\mathrm{SI}=23.39)$. However, MBS extract might harbor some advantages over ribavarin such as safety, low cost, and its natural origin which together allow using MBS extract, and/or the underlying antiviral component, in higher doses and longer periods than ribavarin; this ultimately leads to equal or superior therapeutic values of MBS extract to that of ribavarin. For these reasons, the current trend of searching antimicrobial has moved to the natural products for the direct use of natural extracts or the use of the responsible antimicrobial component.

HSV-1 can establish latent infection in the nervous system and usually leads to life-threatening diseases in immunocompromised individuals upon reactivation [36]. Treatment with conventional nucleoside analogues such as Acyclovir is effective in most cases, but drug-resistance may arise due to prolonged treatment in immunocompromised individuals [37]. The recovery of the same Acyclovir-resistant virus during recurrent infections suggests that Acyclovir-resistant HSV-1 establishes latency and reactivates intermittently in highly risk individuals [38]. Moreover, a well-known side effect of prolonged Acyclovir treatment is kidney nephrotoxicity [39]. Accordingly, it is conceived so far that the plants' derived antiHSV1 drugs might be the only way that can solve these problems.

MBS extract showed higher virucidal than prophylactic activities against HSV-1. However, both activities were well evident. The virucidal activity against HSV-1 was high $(\mathrm{SI}=18.23)$ and the prophylactic activity was fair enough to be considered effective $(\mathrm{SI}=10.9)$ against HSV-1 infection. But the most interesting, there was no significant difference found between the prophylactic and the virucidal actions of MBS extract and that of the HSV-1 standard drug, Acyclovir. Accordingly, MBS extract could be used in the treatment and/or in the prophylaxis of HSV-1 against HSV-1 infection at comparable levels to that of Acyclovir.

MBS extract showed capability for killing HSV-1 and RSV viruses which is a sign for a prominent virucidal activity. In addition, it exerted antiviral prophylactic activity in both Vero cells and MRC-5 host cells against both RSV and HSV-1 viruses, respectively. Therefore, there was a need to elucidate part of the underlying mechanism(s) exerted by this extract on protecting virus-specific host cells against the infection and cytopathic effects of the tested viruses. For this goal, the induction for the synthesis of four cytokines known as actively engaged in the antiviral activity of mammalian cells against RNA and DNA viruses, namely IFN $\beta$, IL- 1 , IL-6, and TNF $\alpha$, was studied [40-47].

Starting with the most prominent antiviral cytokine, IFN $\beta$, this cytokine was remarkably induced by MBS extract in extract-pretreated HSV-1-infected MRC-5 cells. In addition, this extract induced IFN $\beta$ expression in non-infected cells treated with this extract. These

Table 12 Comparisons of the $50 \%$ inhibitory concentration (IC50) of MBS extract on HSV-1 at the best time for each protocol

\begin{tabular}{lllll}
\hline Protocol vs Protocol & Time vs Time & IC50 vs IC50 & $P$ value \\
\hline${ }^{a}$ IVR vs ${ }^{b}$ DVI & 1 h vs $2 \mathrm{~h}$ & $12.72 \pm 1.12$ vs $7.62 \pm 0.71$ & 0.009 & Significant \\
\hline
\end{tabular}

Note: ${ }^{a} I V R$ : the inhibition in virus infection after specific cell treatment. ${ }^{b} \mathrm{DVl}$ : the direct virus inactivation 
Table 13 Comparisons of the selectivity index (SI) of antiviral activity on HSV-1 between prophylactic (IVR) and virucidal (DVI) at best time for MBS extract and between that of MBS extract and the standard drug (Acyclovir)

\begin{tabular}{llllll}
\hline Extract & Protocol vs Protocol & Time vs Time & SI vs SI & $P$ value \\
\hline MBS & ${ }^{a}$ IVR vs ${ }^{b}$ DVI & $1 \mathrm{~h}$ vs $2 \mathrm{~h}$ & $10.9 \pm 0.96$ vs $18.23 \pm 1.69$ & 0.009 & Significant \\
MBS vs Acyclovir & ${ }^{a}$ IVR vs ${ }^{a}$ IVR & $1 \mathrm{~h}$ vs $1 \mathrm{~h}$ & $10.9 \pm 0.96$ vs $15.04 \pm 1.9$ & 0.06 & Non-significant \\
MBS vs Acyclovir & ${ }^{b}$ DVI vs ${ }^{b}$ DVI & $2 \mathrm{~h}$ vs $2 \mathrm{~h}$ & $18.23 \pm 1.69$ vs $22.56 \pm 1.11$ & 0.05 & Non- Significant \\
\hline
\end{tabular}

Note: aIVR: the inhibition in virus infection after specific cell treatment. ${ }^{\mathrm{b}} \mathrm{DVI}$ : the direct virus inactivation

findings provided evidence on the ability of MBS extract to charge human cells ready for any concurrent and subsequent viral infections. However, the interesting feature which was found here that MBS extract induced IFN $\beta$ in non-infected cells much lower than in infected cells. This feature adds privilege on using MBS extract or the antiviral components that will be isolated from it because these agents selectively induce IFN $\beta$ most highly in infected cells only. Therefore, using MBS extract might override the side effects of using interferons therapy which usually causes febrile reaction, headache, and unwanted systematic immune reactions $[48,49]$.

For TNFo, this cytokine was recently found to be important antiviral as well as anticancer cytokine [41, 43, 50-52]. MBS extract showed good inducing capacity for TNF $\alpha$ expression by MRC- 5 cells. The highest level of TNF $\alpha$ induction by MBS extract was observed in treated-infected cells followed by treated cells, infected cells, and finally by control cells (non-treated non-infected cells). These findings granted clues on the ability of MBS extract to selectively induce higher levels of TNF $\alpha$ by human cells when these cells are being infected by viruses. Therefore, MRC5 cells needed two signals for the expression of the maximum levels of TNF $\alpha$; these signals came from the extracts' pretreatment and HSV-1 infection. Like the case of IFN $\beta$, the relatively selective induction of TNF $\alpha$ expression in virally infected human cells pretreated with MBS extract can also override the systemic side effects for using synthetic TNF $\alpha$ products [53]. Wei et al. found that TNF $\alpha$ levels, locally and systematically, increase significantly in mice with HSV-1 infection; moreover, after treatment with Acyclovir for HSV-1 infection, the level of TNF $\alpha$ was largely decreased [54]. This report revealed the pivotal role of TNFo in counteracting DNA viruses such as HSV-1. As a proof for the strong link between TNF $\alpha$ induction and viral infection, mainly by HSV-1, a previous study [43] found that TNF $\alpha$ and IL-1 cytokines were produced largely by microglial cells during non-productive infection while other cytokines, including interferons, were not induced by such weak infective cycle. It was revealed that TNF induce multiple antiviral mechanisms, and to synergize with interferon (IFN)-gamma in promoting antiviral activities; and the antiviral activity of TNF is mediated via both TNF receptors, TNFR1 (p55) and TNFR2 (p75), in vivo [55]. Recently, it was found that the combination of TNF $\alpha$ and IFN $\beta$ induces a novel synergistic antiviral state that is highly distinct from that induced by either cytokine alone [56]. Hence, MBS extract is believed to exert a synergistic antiviral effect by inducing both TNF $\alpha$ and IFN $\beta$ cytokines.

Several reports proved the antiviral role of IL-1 and IL-6 in human and murine cells [43, 46, 47, 57-60]. The expression of IL-1 was highest in treated-infected cells, followed equally by treated cells alone and infected cells alone, and finally the control cells. For IL-6, the highest expression was in treated-infected cells, followed by treated cells, infected cells, and control cells. Like the case of TNF $\alpha$ and IFN $\beta$, MBS extract induced the highest level of expression of IL-1 and IL-6 in HSV-1 infected cells already treated with the extract. Thus MBS extract showed selectivity in inducing all tested cytokines. This phenomenon points out to the possibility that TNF $\alpha$, IFN $\beta$, IL- 1 , and IL- 6 are induced by MBS extract via the same mechanism(s). One of the proposed mechanisms to induce all these cytokines to create antiviral resistance is the induction of nuclear factor-kappa B (NF-kappa-B), transcriptional factor. Recent reports stated and proved the antiviral role of NF-kappa-B [61, 62]. Moreover, antiviral resistance against HSV-1 via TNF $\alpha$ was found to be attributed to NF-kappa-B [42].

Table 14 The measured concentrations of antiviral cytokines in control, MBS extract treated, HSV-1 infected, and MBS extract treated \& HSV-1 infected MRC-5 cells

\begin{tabular}{lllll}
\hline Cytokine & Control cells & Treated cells & Infected cells & Treated-infected cells \\
& Mean \pm 2 SE $(\mathrm{pg} / \mathrm{ml})$ & Mean \pm 2 SE $(\mathrm{pg} / \mathrm{ml})$ & $88.49 \pm 7.49$ & $181.42 \pm 15.6$ \\
IFNB & $53.7 \pm 5.72$ & $91.78 \pm 7.98$ & $90.58 \pm 9.32$ & $145.72 \pm 13.51$ \\
IL-1 & $36.84 \pm 6.22$ & $76.16 \pm 9.24$ & $75.92 \pm 11.54$ & $190.31 \pm 10.6$ \\
IL-6 & $58.11 \pm 3.85$ & $115.24 \pm 10.1$ & $79.43 \pm 10.04$ & $174.67 \pm 14.77$ \\
TNFa & $40.3 \pm 4.81$ & $105.97 \pm 8.42$ & & Mean $\pm 2 S E(\mathrm{pg} / \mathrm{ml})$ \\
\hline
\end{tabular}




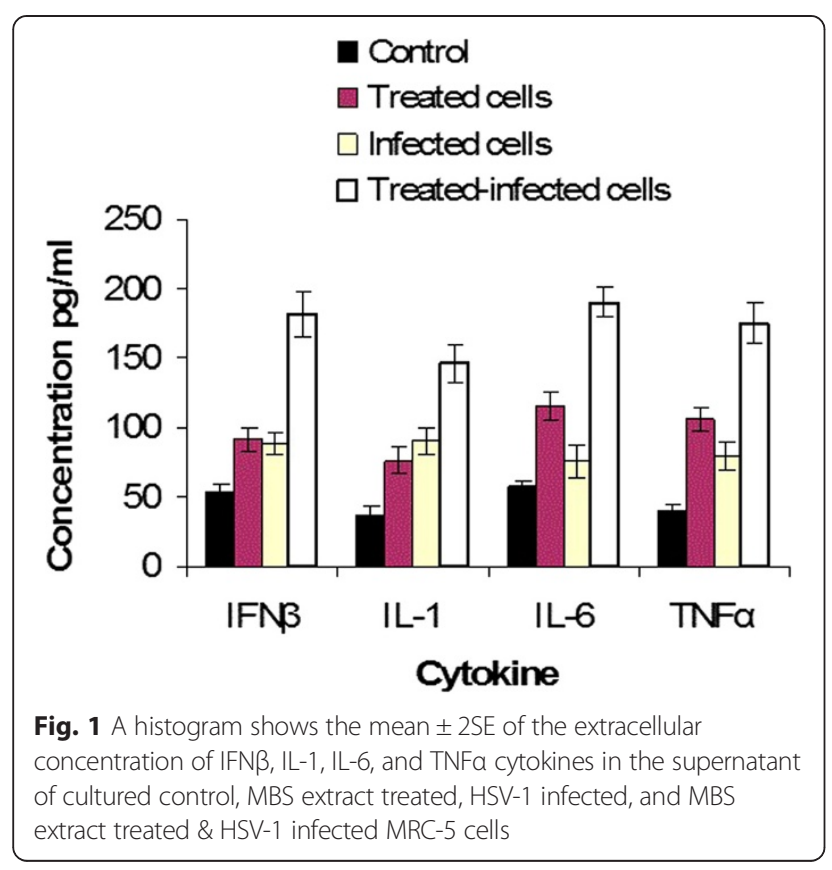

\section{Conclusion}

The primary antiviral assay revealed noticeable antiviral activities against RSV and HSV-1 by MBS extract. The SI reflected high selectivity and low cytotoxicity of MBS extract over RSV, Vero cells, HSV-1, and MRC-5, respectively. MBS extract was more effective as a virucidal agent than a prophylactic agent on RSV and HSV-1. Hence, MBS extract can be used in the treatment and in the prophylaxis against both HSV-1 and RSV infection with comparable levels to that of standard drugs but with much more safety. MBS extract revealed ability to create a highly inducible status in virally infected cells for the expression of high levels of IFN $\beta$, TNF $\alpha$, IL-1, and IL-6 cytokines which may explain in part its prophylactic activity. These cytokines proved to play essential and synergistic role in the antiviral resistance of human cells. Collectively, the importance of these results comes from their novelty. The effective anti-RSV and antiHSV1 activities of MBS extract were significant. The findings of this study may open the gate wide to develop new antiviral agents from inexpensive and safe sources like mung bean sprout.

\section{Methods}

\section{Preparation of the MBS extract}

Fresh mung bean sprouts (MBS), devoid of any preservative antimicrobials, was purchased from local markets and were identified by the leader of the research team, namely Dr. Fatimah Abu Bakar. A voucher specimen of MBS has not been deposited in a publicly available herbarium as MBS used is that of the daily used produce. The mung bean sprouts were left to dry in dark area for three days at room temperature $23-25{ }^{\circ} \mathrm{C}$. After the dryness of sprouts, they were ground to powder. The ground powder was extracted 1:10 wt/v with $2.4 \mathrm{M} \mathrm{HCl}$ acidified methanol (Merck, Darmstadt, Germany) to extract all components of phenolic compounds, free and conjugated, [63]; the ground powder was then soaked in dark area for three days at room temperature. The supernatant was collected after filtration and the fresh solvent was added to the plant material. The extraction procedure was repeated twice and the collected extract was evaporated to dryness under vacuum at $40{ }^{\circ} \mathrm{C}$ by using rotary evaporator. To remove the effect of the acidity from the crude extract, the crude extract was neutralized. The $\mathrm{pH}$ of MBS extract was adjusted to be neutral ranging from 6.8 to 7.0. The dried extract was stored at $-18{ }^{\circ} \mathrm{C}$ in a desiccant form until further use.

\section{Preparation of the stock extract}

The stock extract for MBS was prepared by redissolving in dimethyl sulfoxide (DMSO) $0.1 \%$, (BIO BASIC INC., NY, USA). This concentration was shown to be non toxic to cell culture [64]. The dissolved suspension was centrifuged at $134 \mathrm{~g}$ for $10 \mathrm{~min}$ and filtrated by $0.22 \mu \mathrm{m}$ Millipore filters (Nalgene, UK). The stock was stored at $-20{ }^{\circ} \mathrm{C}$ until it further use. The concentration of the stock extract was determined as required.

\section{Specific cells propagation and cryopreservation}

African green monkey kidney cells (Vero; ATCC CCL-81) were used to culture human respiratory syncytial virus (RSV strain A-2: ATCC VR-1540) and human herpes simplex virus type 1 (HSV-1 strain HF: ATCC VR-260) while human embryonic lung fibroblast cells (MRC-5; ATCC CCL-171) were used to culture human herpes simplex virus type 1 (HSV-1 strain HF: ATCC VR-260) only. Cells were propagated as monolayer at $37{ }^{\circ} \mathrm{C}$ under a humidified $5 \% \mathrm{CO}_{2}$ atmosphere in Roswell Park Memorial Institute-1640 (RPMI-1640) culture medium w/L-glutamine (biowest, Florida, USA) supplemented with Fetal Bovine Serum (FBS) $10 \%$, (Sigma, Germany), 50 U/ml penicillin-streptomycin (biowest, Florida, USA), and $2.5 \mu \mathrm{g} / \mathrm{ml}$ amphotericin B (biowest, Florida, USA). Part of the cells were cryopreserved for future work in liquid nitrogen $\left(-196{ }^{\circ} \mathrm{C}\right)$ after suspending them in RPMI-1640 cryospreserved medium supplemented with FBS $10 \%$, DMSO $20 \%, 50 \mathrm{U} / \mathrm{ml}$ of penicillin-streptomycin, and $2.5 \mu \mathrm{g} / \mathrm{ml}$ amphotericin B.

\section{Virus propagation (RSV and HSV-1)}

RSV and HSV-1 were propagated on $70-80 \%$ and $90 \%$ confluent Vero cell monolayer, respectively, in RPMI1640 maintenance medium with $2 \%$ FBS and antibiotics as described above. Viruses were stored at $-80{ }^{\circ} \mathrm{C}$ until they were used again. 


\section{RSV titration by endpoint titration technique}

Vero cells of $1 \times 10^{5}$ cell/well were grown in RPMI-1640 culture medium in 96-well flat-bottom tissue culture plates (Orange Scientific, Europe). After $24 \mathrm{~h}$ of incubation, the medium was removed and the monolayer cells were incubated for one and half hour at $37^{\circ} \mathrm{C}$ with serial 10-fold diluted virus suspensions in phosphate buffer saline (PBS), (CALBIOCHEM, Darmstadt, Germany). After adsorption, the inoculum was removed and $200 \mu \mathrm{l} /$ well RPMI-1640 maintenance medium with $2 \%$ FBS were added. Negative Control wells represented Vero cells without virus. All plates were incubated at $37{ }^{\circ} \mathrm{C}$ in a humidified $5 \% \mathrm{CO}_{2}$ atmosphere and were observed daily for cytopathic effect (CPE). Estimation of the endpoints was made after $48 \mathrm{~h}$. Titers were calculated as $50 \%$ tissue culture infectious doses (TCID50)/ml, using the Reed and Muench method [65] to estimate endpoints. The titration was repeated for three times with four replicates for each virus dilution at each time.

\section{HSV-1 titration by plaque assay}

HSV-1 was titrated using plaque assay. For this purpose Vero cells of $1 \times 10^{5}$ cell/well were grown in RPMI-1640 culture medium using 6-well tissue culture plates (Orange Scientific, Europe). After $24 \mathrm{~h}$, the medium was removed and the monolayer cells were incubated with serial 10-fold diluted virus suspensions in PBS for $1 \mathrm{~h}$ at $37{ }^{\circ} \mathrm{C}$. After removing the inoculum, the infected and non infected cells were overlaid with RPMI-1640 culture medium containing $0.5 \%$ agarose type VII (Sigma, Steinheim, Germany). Negative control wells represented Vero cells without virus. After $48 \mathrm{~h}$, the infected cells were fixed by $1 \%$ formaldehyede (Sigma, Steinheim, Germany) for three days at room temperature. Afterwards, the agarose layer was removed and the infected cells were stained by $0.05 \%$ neutral red (Sigma, Steinheim, Germany) for $2 \mathrm{~h}$ at room temperature. Plaques were counted and virus titers expressed as plaque forming units (PFU)/ml $[36,66]$. The titration was repeated for three times with two replicates for each virus dilution at each time.

\section{Cytotoxicity assay}

The cytotoxic activities of MBS extract and standard antiviral drugs on virus specific cells were evaluated using MTT assay. In this colorimetric assay, yellow MTT 3-[4,5-dimethylthiazol-2-yl]-2,-diphenyltetrazolium bromide, (CALBIOCHEM, Darmstadt, Germany) is reduced to purple formazan by live cells' mitochondrial enzymes $[67,68]$ and the color change can be quantified by measuring the absorbance at certain wavelength. After incubating the virus-specific cells with each extract or the standard drugs, $50 \mu \mathrm{l} \mathrm{MTT}(5 \mathrm{mg} / \mathrm{ml})$ and $200 \mu \mathrm{l}$ of RPMI-1640 culture medium were added to each well. The plates were incubated in a humidified $5 \% \mathrm{CO}_{2}$ atmosphere for $4 \mathrm{~h}$ at $37{ }^{\circ} \mathrm{C}$. Later, $200 \mu \mathrm{l} /$ well DMSO was added to solublize the formazan crystal. The plates were shaked for $10 \mathrm{~min}$ and the absorbance was measured at $540 \mathrm{~nm}$ (reference $690 \mathrm{~nm}$ ) using a 96-well plate ELISA reader (Sunrise Basic Tecan, Grödig, Austria). Each experiment was repeated for three times with four wells per dilution in each run. The $50 \%$ cytotoxic concentration (CC50) was defined as the highest concentration that caused $50 \%$ death or was cytotoxic to $50 \%$ of virus-specific cells. Cytotoxicity was calculated using the following formula:

$$
\text { Cytotoxic } \%=100-[(\text { ODt } / \text { ODc }) \times 100]
$$

Where (ODt) indicates the optical density of the treated cells and (ODc) indicates the optical density of the negative control or the untreated cells [15].

The cytotoxic effects of MBS extract on vero and MRC- 5 cells Vero cells were cultivated as $1 \times 10^{5}$ cell/well in 96-well flat bottom tissue culture plates. MRC- 5 cells were cultivated as $3 \times 10^{4}$ cell/well in 96-well flat bottom tissue culture plates. After $24 \mathrm{~h}$ of incubation at $37{ }^{\circ} \mathrm{C}$ in a humidified $5 \% \mathrm{CO}_{2}$ atmosphere, the monolayer cells were exposed to 2-fold serial dilutions of MBS extract in RPMI-1640 maintenance medium. Stock extract $(600 \mathrm{mg} / \mathrm{ml})$ was used in this assay. MBS serial dilutions ranged from 300 to $9.37 \mathrm{mg} / \mathrm{ml}$. Each well contained $100 \mu \mathrm{l}$ of extract dilution and $100 \mu \mathrm{l}$ of RPMI-1640 maintenance medium. The negative control wells contained $100 \mu \mathrm{l}$ of solvent ( $0.1 \%$ DMSO) and $100 \mu \mathrm{l}$ of RPMI-1640 maintenance medium. All the plates were incubated for another $24 \mathrm{~h}$ in the same conditions. Afterwards, the wells' contents were removed and replaced with $200 \mu \mathrm{l} /$ well maintenance medium; then, plates were incubated for $48 \mathrm{~h}$ at the same conditions. The effects of the extract were monitored daily though microscopic examination.

\section{The cytotoxic effect of the standard drugs ribavirin and acyclovir}

The cytotoxic activity of the RSV standard drug Ribavirin (Sigma, Steinheim, Germany) and the cytotoxic effect of the HSV-1 standard drug Acyclovir (Sigma, Steinheim, Germany) were determined in order to calculate the CC50 for these two standard drugs. Vero $\left(1 \times 10^{5}\right.$ cell/well $)$ and MRC-5 $\left(3 \times 10^{4}\right.$ cell/well) cells were cultured in 96-well flat bottom tissue culture plates with RPMI-1640 culture medium. After $24 \mathrm{~h}$ of incubation at $37{ }^{\circ} \mathrm{C}$ in humidified $5 \% \mathrm{CO}_{2}$, all the wells' contents were removed and the cells were incubated with 2-fold serial dilutions of Ribavirin and Acyclovir prepared in RPMI-1640 maintenance medium with final volume of $200 \mu \mathrm{l} /$ well. Negative control wells contained cells with maintenance medium $(200 \mu \mathrm{l} /$ well $)$. 
All the plates were incubated for $24 \mathrm{~h}$ at the same conditions. The Ribavirin and Acyclovir stock solutions ( $1 \mathrm{mg} / \mathrm{ml}$ and $0.06 \mathrm{mg} / \mathrm{ml}$, respectively) were prepared in PBS solution at serial dilutions ranged from 0.5 to 0.007 and 0.03 to $0.0005 \mathrm{mg} / \mathrm{ml}$, respecitvely. After $24 \mathrm{~h}$, the wells' contents were removed and replaced with $200 \mu \mathrm{l} /$ well maintenance medium. The plates were incubated for another $48 \mathrm{~h}$ at the same conditions. The cells condition was microscopically checked daily.

\section{Virus yield reduction assay}

The antiviral activities of MBS extract on RSV and HSV-1 yields were evaluated to calculate the virus titer reduction factor (RF). RF represents the virus titer in the absence of a drug over the virus titer in the presence of a drug. $\mathrm{RF} \geq 10^{3}$ shows a strong antiviral activity, $\mathrm{RF}=10^{2}$ shows a moderate antiviral activity and $\mathrm{RF}=10^{1}$ shows slight antiviral activity [13, 14].

\section{RSV and HSV-1 yield reduction assays}

This experiment was performed according to the method described by [69] with some modifications for RSV and by Suzutani and Behbahani and with some modifications [70, 71] for HSV-1. For RSV, Vero cells were cultivated as $1 \times 10^{5} \mathrm{cell} /$ well in 96-well flat bottom culture plates in RPMI-1640 culture medium and for HSV-1, MRC- 5 cells were cultivated as $\left(3 \times 10^{4}\right.$ cell/well $)$ in 96-well flat bottom culture plates in RPMI-1640 culture medium. After $24 \mathrm{~h}$ of incubation at $37^{\circ} \mathrm{C}$ in a humidified $5 \% \mathrm{CO}_{2}$ atmosphere, the medium was removed and the cell monolayer was exposed to $100 \mu \mathrm{l} /$ well of RSV virus suspension in PBS of $3.16 \times 10^{3} \mathrm{TCID} 50 / \mathrm{ml}$ for $1.30 \mathrm{~h}$ and in the case of HSV-1, the virus suspension was in PBS as $5.01 \times 10^{3} \mathrm{PFU} / \mathrm{ml}$ for $1 \mathrm{~h}$.

The virus suspension was removed and replaced with $200 \mu \mathrm{l} /$ well of the extract non-cytotoxic 2-fold serial dilutions (100 $\mu \mathrm{l} /$ well $)$ and RPMI-1640 maintenance medium (100 $\mu \mathrm{l} /$ well). Only $200 \mu \mathrm{l} /$ well of RPMI-1640 maintenance medium was added to the positive and negative control wells. The positive control wells contained cells with virus without treatment. The negative control wells contained cells with maintenance medium only without virus and without treatment. For RSV, the stock extract of MBS used was $441.92 \mathrm{mg} / \mathrm{ml}$ at serial dilutions ranging from 220.96 to $13.81 \mathrm{mg} / \mathrm{ml}$ while, for HSV-1, the stock solution was $273.16 \mathrm{mg} / \mathrm{ml}$ at serial dilutions ranging from 136.58 to $8.53 \mathrm{mg} / \mathrm{ml}$. All the plates were incubated in a humidified $5 \% \mathrm{CO}_{2}$ atmosphere for $48 \mathrm{~h}(\mathrm{RSV})$ and $24 \mathrm{~h}(\mathrm{HSV}-1)$ at $37{ }^{\circ} \mathrm{C}$. Later, three steps of freezing at $-80{ }^{\circ} \mathrm{C}$ and thawing at $37{ }^{\circ} \mathrm{C}$ were performed (10 min for each step). The cell monolayer was disrupted and transferred to 1.5 microtubes (Eppendrof, Hamberg, Germany); then it was centrifuged at $2150 \mathrm{~g}$ for $10 \mathrm{~min}$. Two hundred microliters of RSV- infected Vero cells and 500 ul of HSV-1-infected MRC-5 cells treated with each MBS extract dilution were transferred to a second Vero cell monolayer already cultured in 24-well culture plates for RSV and 6-well culture plates for HSV-1 (Orange Scientific, Europe). Serial 2fold dilutions of infected Vero cells from the primary plate were prepared in the secondary plates. Each well contained the infected Vero cells from the primary plate, which was exposed to certain extract dilution, plus RPMI-1640 maintenance medium with the final volume of $200 \mu \mathrm{l} /$ well for RSV and $500 \mathrm{ul} /$ well for HSV-1 except for the first well which contained the infected Vero cells from the primary plate without diluting RPMI-1640 medium. The virus suspensions from the positive control wells of primary plates were transferred to the positive control wells in the secondary plates. All of the plates were incubated for $1.30 \mathrm{~h}$ and $1 \mathrm{~h}$ for RSV and HSV-1 adsorption, respectively. Then, for RSV, all of the wells' contents were removed and replaced with $500 \mu \mathrm{l}$ RPMI-1640 maintenance medium and incubated in a humidified $5 \% \mathrm{CO}_{2}$ atmosphere for $48 \mathrm{~h}$ at $37{ }^{\circ} \mathrm{C}$. The negative control wells contained cells without virus or the initial extract dilution. The primary and secondary plates' preparations were repeated three times with four replicates of the extract dilution. After $48 \mathrm{~h}$ the virus titer was estimated by endpoint titration method as TCID $50 / \mathrm{ml}$ see section. For HSV-1, all the wells' contents were removed and the cells were overlaid with RPMI-1640 culture medium containing $0.5 \%$ agarose type VII. The next steps were carried out as mentioned earlier in virus titration using plaque assay. The primary and secondary plates were repeated three times with four and two replicates to each extract dilution for the primary and secondary plates, respectively, in each run.

\section{Virucidal activity assay}

The virucidal activity assay determines the ability of MBS extract to directly inactivate the extracellular RSV and HSV-1. The viruses were incubated with the non toxic concentrations of extract for different time intervals. Then, the treated virus suspensions were transferred to a ready cell monolayer of virus specific cell line and incubated for $72 \mathrm{~h}$. In other words, cultures were incubated until the wells containing infected cells with untreated virus (positive control) showed complete $(100 \%)$ cytopathic effect. In order to compare the antiviral activities of MBS extract with the antiviral activity of the standard drug, the same steps were repeated using the non-cytotoxic concentration of standard drug. The standard drugs were incubated with the viruses for a duration of time equal to that needed by the extracts to cause significant virucidal activity. The cytopathic reduction assay was estimated by recording the level of the virus-induced $\mathrm{CPE}$ after the incubation time and was 
recorded as CPE percentage in comparison with the positive and negative controls, as follows: (0\% CPE), (0-25 \% CPE), (25-50\% CPE), (50-75 \% CPE) and (75-100\% CPE), [17, 72]. The concentration that reduced $50 \%$ of CPE with respect to control virus was estimated from the plots of the absorbance data obtained from MTT assay. Moreover, in order to confirm the MTT assay results, the monolayer was observed microscopically to estimate virus-induced CPE\% as mentioned above [73]. The concentration that reduced $50 \%$ of CPE was also defined as $50 \%$ inhibitory concentration (IC50). IC50 was determined as the lowest concentration of extract that caused $50 \%$ inhibition of the virus-induced CPE. It was calculated using the following formula:

Inhibition $\%=[(\mathrm{ODt}-\mathrm{ODcv}) /(\mathrm{ODcd}-\mathrm{ODcv}) \times 100]$

Where ODt is the test absorbance and ODcv and ODcd are the absorbance of control virus and control cell, respectively [74].

The selective index (SI), which is an important parameter to evaluate the antiviral activity, was calculated from the ratio CC50/IC50 [75]. The assay was repeated three times with four replicates for each test in each run.

\section{Virucidal activity against RSV and HSV-1}

The effects of non cytotoxic concentrations of MBS extract on the extracellular RSV and HSV-1 were investigated by incubating $3.16 \times 10^{3} \mathrm{TCID} 50 / \mathrm{ml}$ of RSV and $5.01 \times 10^{3} \mathrm{PFU} / \mathrm{ml}$ of $\mathrm{HSV}-1$ suspensions in PBS with 2-fold serial dilutions of MBS extract. The MBS stock extract was $441.92 \mathrm{mg} / \mathrm{ml}$ for RSV and $273.16 \mathrm{mg} / \mathrm{ml}$ for HSV-1 at serial dilutions ranging from 220.96 to $13.81 \mathrm{mg} / \mathrm{ml}$ and 136.58 to $8.53 \mathrm{mg} / \mathrm{ml}$, respectively. Using $1.5 \mathrm{ml}$ microtubes, $150 \mu \mathrm{l}$ of virus suspension were incubated with $150 \mu \mathrm{l}$ of MBS extract serial dilution in RPMI-1640 maintenance medium. The tubes were incubated in humidified $5 \% \mathrm{CO}_{2}$ at $37{ }^{\circ} \mathrm{C}$ for zero, 1 , and $2 \mathrm{~h}$. Ninety six-well flat bottom tissue culture plates with Vero cell monolayer $\left(1 \times 10^{5}\right.$ cell/well $)$, for RSV, and with MRC-5 cell monolayer $\left(3 \times 10^{4}\right.$ cell/well), for HSV-1, were prepared in advance. The virus suspension with the extract serial dilutions of zero hour time of incubation was directly transferred to the ready tissue culture plates and incubated for $1.30 \mathrm{~h}$ to enable virus adsorption. The same procedure was carried out for other microtubes after 1 and $2 \mathrm{~h}$ time of incubation. After virus adsorption, the wells' contents were removed and replaced with $200 \mu \mathrm{l} /$ well maintenance medium and incubated for $72 \mathrm{~h}$ at the same conditions. Then, two hundred microliters of maintenance medium were added to the negative control wells (cells without virus or treatment) and to the positive control wells (cells with virus and without treatment), [76, 77].
The same procedure was repeated on Vero and MRC5 cell monolayers using the RSV standard drug 'Ribavirin' and the HSV-1 standard drug 'Acyclovir' except for the following differences: the non cytotoxic 2-fold serial dilutions of Ribavarin and Acyclovir ranged from 2.28 to $0.018 \mathrm{mg} / \mathrm{ml}$ and 0.3516 to $0.0027 \mathrm{mg} / \mathrm{ml}$ prepared from stock solutions $(4.56 \mathrm{mg} / \mathrm{ml})$ and $(0.7 \mathrm{mg} / \mathrm{ml})$ in PBS, respectively. RSV was incubated with Ribavirin only for $1 \mathrm{~h}$ before the addition to Vero cell monolayer in 96-well flat bottom tissue culture plates while HSV-1 was incubated only for $2 \mathrm{~h}$ with Acyclovir before the addition to the ready MRC-5 cell monolayer in 96-well flat bottom tissue culture plates.

\section{Prophylactic activity assay}

In order to evaluate the prophylactic activity of MBS extract on virus specific cells, non cytotoxic extract serial dilutions were incubated with the cells before the virus addition. In order to compare the prophylactic activities of MBS extract with the standard drug of each virus, the standard drugs were incubated with the cells only for duration of time needed by the extract to show significant prophylactic activity. The $\mathrm{CPE} \%$ together with the concentration that inhibited $50 \%$ of virus-induced CPE or the $50 \%$ inhibitory concentration (IC50) and the (SI) were calculated as mentioned earlier. The assay was repeated three times with four replicates for each well.

\section{The prophylactic effects of the MBS extract on Pre-RSV-infection vero cell line and Pre-HSV-1 infection MRC-5 cell line}

A monolayer of Vero cells $\left(1 \times 10^{5}\right.$ cell/well $)$ and MRC-5 cells $\left(3 \times 10^{4}\right.$ cell/well $)$ in 96-well flat bottom tissue culture plates were treated with 2 -fold serial dilutions of MBS extract. The MBS stock extract was, for RSV, $441.92 \mathrm{mg} / \mathrm{ml}$ at serial dilutions from 220.96 to $13.81 \mathrm{mg} / \mathrm{ml}$ and, for $\mathrm{HSV}-1,273.16 \mathrm{mg} / \mathrm{ml}$ at serial dilutions from 136.58 to $8.53 \mathrm{mg} / \mathrm{ml}$. The plates were divided into two groups. The first group was incubated with the extract for $30 \mathrm{~min}$ and the second group was incubated with the extract for $1 \mathrm{~h}$ in humidified $5 \% \mathrm{CO}_{2}$ incubator at $37{ }^{\circ} \mathrm{C}$. All of the plates contained extract dilutions as well as RPMI-1640 maintenance medium with the final volume of $200 \mu \mathrm{l} /$ well. The wells' contents were removed after the incubation time for each group and the RSV suspension of $3.16 \times 10^{3} \mathrm{TCID} 50 / \mathrm{ml}$ and HSV- 1 suspension $5.01 \times 10^{3} \mathrm{PFU} / \mathrm{ml}$ in PBS were added to all the wells except for the negative control wells. The plates were incubated for $1.30 \mathrm{~h}$ at the same conditions. After the virus adsorption, the virus suspension was removed and replaced with $200 \mu \mathrm{l} /$ well of maintenance medium. The positive control wells contained infected cells without treatment. Two hundred microliters of maintenance medium were added to the negative control wells (cells 
without virus or treatment). All of the plates were incubated for $72 \mathrm{~h}$ at the same conditions $[78,79]$.

The prophylactic activity of the standard RSV drug 'Ribavirin' on Vero cell monolayer and the prophylactic activity of HSV-1 standard drug 'Acyclovir' on MRC-5 cell monolayer were evaluated using the same procedure described above except for the following differences: the non cytotoxic 2-fold serial dilutions of Ribavarin ranged from 2.28 to $0.018 \mathrm{mg} / \mathrm{ml}$ prepared from stock solution of $4.56 \mathrm{mg} / \mathrm{ml}$ in PBS while the non cytotoxic 2-fold serial dilutions ranged from 0.3516 to $0.0027 \mathrm{mg} / \mathrm{ml}$ prepared from stock solution of $0.7 \mathrm{mg} / \mathrm{ml}$ in PBS. The cells were incubated with Ribavirin for $1 \mathrm{~h}$ before the addition of RSV to the ready Vero cell monolayer in 96-well flat bottom tissue culture plates while the cells were incubated with Acyclovir for $1 \mathrm{~h}$ before the addition of HSV-1 to the ready MRC-5 cell monolayer in 96-well flat bottom tissue culture plates.

\section{Cytokine production by human embryonic fibroblast cell lines (MRC-5) in response to HSV-1 infection and extract's treatment \\ The preparation of MRC- 5 cells supernatants}

The level of antiviral cytokines, IFN $\beta$, TNF $\alpha$, IL-1, and IL-6, was investigated in four groups of MRC-5 cells. The first group was composed of extract-untreated and HSV-1-non-infected MRC-5 cells (the control cells); the second group was composed of HSV-1-infected cells without extract treatment (infected cells); the third group was composed of extract-treated cells without HSV-1 infection (treated cells); and the fourth group was composed of extract-pretreated and HSV-1-infected cells (treated-infected cells). A number of $3 \times 10^{4}$ cell/well of MRC-5 cells were grown in RPMI-1640 cutlure medium in 96-well flat-bottom tissue culture plates in a humidified $5 \% \mathrm{CO}_{2}$ atmosphere for $24 \mathrm{~h}$ at $37^{\circ} \mathrm{C}$. For the infected, treated, and treated-infected groups, the procedures used were the same to that described in section (3.2.9.2) for prophylaxis of MRC-5 cells against HSV-1 using the extracts' IC50 values of IVR protocols which are $12.72 \mathrm{mg} / \mathrm{ml}$. MBS extract was incubated in triplicates with MRC-5 cells for the optimal time found earlier, namely $1 \mathrm{~h}$. The final volume of wells was $200 \mu \mathrm{l} /$ well. A triplicate of negative control wells contained cells with RPMI-1640 maintenance medium only with final volume of $200 \mu \mathrm{l} /$ well. Afterwards, the supernatants from all the wells were removed and centrifuged at $1000 \mathrm{~g}$ for $10 \mathrm{~min}$ to be ready for the ELISA technique [80].

\section{Sandwich Enzyme-Linked Immunosorbent Assay (ELISA)}

The concentration of antiviral cytokines in the supernatant of culture medium of MRC- 5 cells was determined by sandwich ELISA. MRC- 5 cell line was chosen because MRC-5 cells are human cells able to produce many human cytokines including the antiviral cytokines, TNFo, IFN $\beta$, IL-1, and IL-6. On the other hand, Vero cell line which was used in the antiviral assays done earlier on RSV, was not used in measuring the antiviral cytokines because Vero cells are not of human origin and IFN $\beta$ deficient cells.

The measurement of human TNF $\alpha$ using immunometric assay (EIA) kits (Cayman, USA) was done according to the kit's instructions. In order to prepare the standard curve, the standard of TNF $\alpha$ was reconstituted in EIA buffer. The standard dilutions must be present in the same biological fluid "matrix" as that of the sample to accurately assay unpurified samples. The standard was diluted in the sample matrix (the IC50 of MBS extract in RPMI-1640 culture medium) excluded from the target cytokine, TNF $\alpha$. The standard dilutions, in triplicates, were prepared as 2 -fold serial dilutions ranged from 250 to $3.9 \mathrm{pg} / \mathrm{ml}$ in eight tubes of $15 \mathrm{ml}$ capacity (Orange Scientific, Europe); the 8th tube containing only the sample matrix with zero concentration of the standard. One hundred microliters of the standard or the samples were added to the microtiter plate which was supplied with the kit. The microtiter plate was already coated with monoclonal antibodies specific for TNF $\alpha$. The samples were assayed in triplicates. One hundred microliters of Acetylcholinesterase: TNF $\alpha$ Fab' conjugate were added to the wells of the standards and the samples. The plates were covered with plastic films and incubated overnight at $4{ }^{\circ} \mathrm{C}$. The quantification of the conjugate was achieved by measuring its acetylcholinesterase activity with freshly prepared Ellman's reagent (acetylcholine and 5,5'-dithio-bis-(2nitrobenzoic acid). All of the wells were rinsed 5-6 times with washing buffer after removing their contents. Two hundred microliters of Ellman's reagent were added to all of the wells. The plate was covered with plastic film and incubated for six hours at $25{ }^{\circ} \mathrm{C}$ in shaker incubator. Blank wells contained only Ellman's reagent added to the triplicate wells of the 8th standard (to subtract the color effect). Later, the absorbance (OD) was measured at $412 \mathrm{~nm}$ (reference $690 \mathrm{~nm}$ ) using a 96-well plate ELISA reader. The samples' concentrations were determined by extrapolating OD values of TNF $\alpha$ to the generated linear standard curve (the average absorbance on the vertical axis versus the corresponding standard concentration on the horizontal axis).

For the measurement of the concentration of IFN $\beta$, IL- 1 , and IL- 6 in the supernatant of MRC-5 cell culture medium, an ELISA kit from (abcam, USA) was used. IFN $\beta$, IL-1, and IL- 6 standards were freshly prepared by reconstituting in the standard diluent buffer to give a stock concentration of $400 \mathrm{pg} / \mathrm{ml}$. Two hundred microliters of this stock was added in triplicate to the already coated microtiter plates provided by the kit. Each plate was coated with monoclonal IFN $\beta$, IL-1, or IL-6 specific 
antibodies. From stock wells serial 2-fold dilutions, in triplicates, of IFN $\beta$, IL-1, and IL-6 standards were prepared by diluting the standard in the sample matrix which composed of the IC50 of MBS extract in RPMI1640 medium, excluded from the target cytokines. IFN $\beta$, IL-1, and IL-6 standards' concentrations ranged from 400 to $12.5 \mathrm{pg} / \mathrm{ml}$; and the last standard contained zero concentration of IFN $\beta$, IL-1, and IL-6 standards in sample matrix. The prepared samples $(100 \mu \mathrm{l} /$ well $)$ were added, in triplicates. Then, $50 \mu \mathrm{l}$ of freshly prepared biotinylated anti- IFN $\beta$, IL-1, or IL- 6 antibodies, diluted in biotinylated antibody diluents, were added to all of the wells. The plates were covered with plastic films and incubated two hours at $25{ }^{\circ} \mathrm{C}$. Later, all the wells' contents were removed and the wells were washed for two times with washing buffer. One hundred microliter of freshly prepared Streptavidin-horse radish peroxidase (Streptavidin-HP), diluted in HP diluent, were added to all wells. The plates were covered and incubated for $30 \mathrm{~min}$ at $25{ }^{\circ} \mathrm{C}$. Two washes with washing buffer were done to rinse all the wells. One hundred microliters of freshly prepared substrate solution; chromogen TMB (5-thio-2-nitrobenzoic acid) were added to the wells and incubated in dark for $20 \mathrm{~min}$. The reaction was terminated by adding $\mathrm{H}_{2} \mathrm{SO}_{4}$, a stopping reagent. The blanks, in triplicates, were composed of the substrate chromogen solution along with the stopping reagent added to the zero standard wells. A colored product was formed in proportion to the level of IFN $\beta$, IL-1, and IL- 6 cytokines in the tested supernatants. The absorbance was measured at $450 \mathrm{~nm}$ (reference $620 \mathrm{~nm}$ ) by ELISA reader. The samples' concentrations were determined by extrapolating OD values of IFN $\beta$, IL-1, or IL-6 samples to the generated linear standard curve.

\section{Data analysis}

Data are presented as mean $\pm 2 \mathrm{SE}$ from three independent experiments. The selectivity index (SI) was determined by the ratio of CC50 to IC50. The effect of the tested MBS extract on the inhibition of viral replication was evaluated by SPSS software version (12.0.0.2). The statistically different effects of the extract on the inhibition of RSV or HSV-1 replication were compared with the control groups using the Student's $t$-test. Differences were considered significant at $P<0.05$.

\footnotetext{
Abbreviations

MBS: Mung bean sprout; RSV: Respiratory syncytial virus; HSV-1: Herpes simplex virus-1; RF: Reduction factor; CPE: Cytopathic effect; MTT: Microculture tetrazolium assay; EPTT: End point titration technique; DVI: Direct Virus Inactivation; IVR: Inhibition of Virus Replication; CC50: Cytotoxic concentration 50; IC50: Inhibitory concentration 50; SI: Selective index; IFNß: Interferon beta; IL-1: Interleukin 1; IL-6: Interleukin 6; TNFa: Tumor necrosis factor alpha.
}

\section{Competing interests}

The authors declare that they have no competing interests.

\section{Authors' contributions}

$A S A, R R H$ and FAB designed the research. $\mathrm{RRH}, \mathrm{ASA}$, and FA did the methodology. FAB and ZS supervised the integrity of methodology and results. $A S A, R R H$, and FAB wrote the manuscript and did the statistical analysis. All authors read and approved the final manuscript.

\section{Acknowledgements}

This research was kindly funded by University Putra Malaysia. We would like to thank the virology laboratory staff at the Faculty of Medicine for their help and support.

\section{Author details}

'Department of Microbiology, College of Medicine, Baghdad University, Baghdad, Iraq. ${ }^{2}$ Institute of Bioscience, University Putra Malaysia, Serdang 43400, Selangor, Malaysia. ${ }^{3}$ Department of Microbiology, College of Medicine, Alnahrain University, PO Box 70030, Baghdad, Iraq. ${ }^{4}$ Faculty of Food Science and Technology, University Putra Malaysia, Serdang 43400, Selangor, Malaysia. ${ }^{5}$ Faculty of Health Sciences and Medicine, University Putra Malaysia, Serdang 43400, Selangor, Malaysia. ${ }^{6}$ Department of Medical Microbiology, Faculty of Medicine "Hamadan University of Medical Sciences (HUMS), Hamadan, llam, Iran.

Received: 22 February 2015 Accepted: 21 May 2015

Published online: 11 June 2015

\section{References}

1. Tisdale M. Monitoring of viral susceptibility: new challenges with the development of influenza NA inhibitors. Rev Med Virol. 2000;10:45-55.

2. Castelo-Soccio L, Bernardin R, Stern J, Goldstein SA, Kovarik C. Successful treatment of Acyclovir-resistant herpes simplex virus with intralesional cidofovir. Arch Dermatol. 2010;146:124-6.

3. Reusser P. Herpesvirus resistance to antiviral drugs: a review of the mechanism, clinical importance and therapeutic options. J Hosp Infect. 1996;33:235-48.

4. Cox PA. Ethnopharmacology and the search for new drugs. Ciba Found Symp. 1990;154:40-7. discussion 47-55.

5. Chavez JH, Leal PC, Yunes RA, Nunes RJ, Barardi CR, Pinto AR, et al. Evaluation of antiviral activity of phenolic compounds and derivatives against rabies virus. Vet Microbiol. 2006;116:53-9.

6. Jassim SA, Naji MA. Novel antiviral agents: a medicinal plant perspective. J Appl Microbiol. 2003;95:412-27.

7. Prichard MN, Turk SR, Coleman LA, Engelhardt SL, Shipman Jr C, Drach JC. A microtiter virus yield reduction assay for the evaluation of antiviral compounds against human cytomegalovirus and herpes simplex virus. J Virol Methods. 1990;28:101-6.

8. Betancur-Galvis LA, Morales GE, Forero JE, Roldan J. Cytotoxic and antiviral activities of Colombian medicinal plant extracts of the Euphorbia genus. Mem Inst Oswaldo Cruz. 2002;97:541-6.

9. Harborne JB. Advances in flavonoid research since 1992. Phytochemistry. 2000;55:481-504

10. Simonetti P, Gardana C, Pietta P. Plasma levels of caffeic acid and antioxidant status after red wine intake. J Agric Food Chem. 2001;49:5964-8.

11. Lin J, Opoku AR, Geheeb-Keller M, Hutchings AD, Terblanche SE, Jager AK, et al. Preliminary screening of some traditional zulu medicinal plants for anti-inflammatory and anti-microbial activities. J Ethnopharmacol. 1999;68:267-74.

12. MCDougall GJ, Shpiro F, Dobson P, Smith P, Blake A, Stewart D. Different polyphenolic components of soft fruits inhibit alpha-amylase and alpha-glucosidase. J Agric Food Chem. 2005:53:2760-6.

13. Fritz D, Venturi CR, Cargnin S, Schripsema J, Roehe PM, Montanha JA, et al. Herpes virus inhibitory substances from Hypericum connatum Lam., a plant used in southern Brazil to treat oral lesions. J Ethnopharmacol. 2007; 113:517-20

14. Vlietinck AJ, Van Hoof L, Totte J, Lasure A, Vanden Berghe D, Rwangabo PC, et al. Screening of hundred Rwandese medicinal plants for antimicrobial and antiviral properties. J Ethnopharmacol. 1995;46:31-47.

15. Chiang LC, Chiang W, Chang MY, Ng LT, Lin CC. Antiviral activity of Plantago major extracts and related compounds in vitro. Antiviral Res. 2002;55:53-62. 
16. Vonthron-Senecheau C, Weniger B, Ouattara M, Bi FT, Kamenan A, Lobstein A, et al. In vitro antiplasmodial activity and cytotoxicity of ethnobotanically selected Ivorian plants. J Ethnopharmacol. 2003:87:221-5

17. Ho WS, Xue JY, Sun SS, Ooi VE, Li YL. Antiviral activity of daphnoretin isolated from Wikstroemia indica. Phytother Res. 2009;24:657-61

18. Lopez BS, Yamamoto M, Utsumi K, Aratsu C, Sakagami H. A clinical pilot study of lignin-ascorbic acid combination treatment of herpes simplex virus. In Vivo. 2009;23:1011-6.

19. Fernandez-Orozco R, Frias J, Zielinski H, Piskula MK, Kozlowska H, Vidal-Valverde C. Kinetic study of the antioxidant compounds and antioxidant capacity during germination of Vigna radiata cv. emmerald, Glycine max cv. jutro and Glycine max cv. merit. Food Chem. 2008;111:622-30.

20. Lee K-G, Shibamoto T. Antioxidant properties of aroma compounds isolated from soybeans and mung beans. J Agric Food Chem. 2000;48:4290-3.

21. Kayden HJ, Traber MG. Absorption, lipoprotein transport, and regulation of plasma concentrations of vitamin E in humans. J Lipid Res. 1993;34:343-58.

22. Ricciarelli R, Zingg JM, Azzi A. The 80th anniversary of vitamin E: beyond its antioxidant properties. Biol Chem. 2002;383:457-65.

23. Nagibina MV, Neifakh EA, Krylov VF, Braginskii DM, Kulagina MG. [The treatment of pneumonias in influenza using antioxidants]. Ter Arkh. 1996;68:33-5.

24. Pertseva NG, Ananenko AA, Malinovskaia W, Klembovskii Al, Burova V, Meshkova EN, et al. [The effect of reaferon and alpha-tocopherol on lipid peroxidation in experimental influenza]. Vopr Virusol. 1995;40:59-62.

25. Lee E, Choi MK, Lee YJ, Ku JL, Kim KH, Choi JS, et al. Alpha-tocopheryl succinate, in contrast to alpha-tocopherol and alpha-tocopheryl acetate, inhibits prostaglandin E2 production in human lung epithelial cells. Carcinogenesis. 2006;27:2308-15.

26. Furuya A, Uozaki M, Yamasaki H, Arakawa T, Arita M, Koyama AH. Antiviral effects of ascorbic and dehydroascorbic acids in vitro. Int J Mol Med. 2008;22:541-5

27. White LA, Freeman CY, Forrester BD, Chappell WA. In vitro effect of ascorbic acid on infectivity of herpesviruses and paramyxoviruses. J Clin Microbiol. 1986;24:527-31.

28. Harakeh S, Jariwalla RJ, Pauling L. Suppression of human immunodeficiency virus replication by ascorbate in chronically and acutely infected cells. Proc Natl Acad Sci U S A. 1990;87:7245-9.

29. Sakagami H, Amano S, Kikuchi H, Nakamura Y, Kuroshita R, Watanabe S, et al. Antiviral, antibacterial and vitamin C-synergized radical-scavenging activity of Sasa senanensis Rehder extract. In Vivo. 2008;22:471-6.

30. Hassimotto NM, Genovese MI, Lajolo FM. Antioxidant activity of dietary fruits, vegetables, and commercial frozen fruit pulps. J Agric Food Chem 2005;53:2928-35.

31. Weisman LE. Respiratory syncytial virus (RSV) prevention and treatment: past, present, and future. Cardiovasc Hematol Agents Med Chem. 2009; 7:223-33.

32. Empey KM, Peebles Jr RS, Kolls JK. Pharmacologic advances in the treatment and prevention of respiratory syncytial virus. Clin Infect Dis. 2010;50:1258-67.

33. Faber $T E$, Kimpen $J L$, Bont $\amalg$. Respiratory syncytial virus bronchiolitis: prevention and treatment. Expert Opin Pharmacother. 2008;9:2451-8.

34. MCKee Jr KT, Huggins JW, Trahan CJ, Mahlandt BG. Ribavirin prophylaxis and therapy for experimental argentine hemorrhagic fever. Antimicrob Agents Chemother. 1988:32:1304-9.

35. Crotty S, Cameron C, Andino R. Ribavirin's antiviral mechanism of action: lethal mutagenesis? J Mol Med. 2002;80:86-95.

36. Su CT, Hsu JT, Hsieh HP, Lin PH, Chen TC, Kao CL, et al. Anti-HSV activity of digitoxin and its possible mechanisms. Antiviral Res. 2008;79:62-70.

37. Holzinger D, Kuhn J, Ehlert K, Groll AH. HSV-1 viremia as a potential cause of febrile neutropenia in an immunocompromised child. J Pediatr Hematol Oncol. 2010;32:e19-21

38. Duan $R$, de Vries RD, van Dun JM, van Loenen FB, Osterhaus AD, Remeijer $L$, et al. Acyclovir susceptibility and genetic characteristics of sequential herpes simplex virus type 1 corneal isolates from patients with recurrent herpetic keratitis. J Infect Dis. 2009;200:1402-14.

39. Sodhi PK, Ratan SK. A case of chronic renal dysfunction following treatment with oral Acyclovir. Scand J Infect Dis. 2003;35:770-2.

40. Boo KH, Yang JS. Intrinsic cellular defenses against virus infection by antiviral type I interferon. Yonsei Med J. 2010;51:9-17.

41. Lundberg P, Welander PV, Edwards 3rd CK, van Rooijen N, Cantin E. Tumor necrosis factor (TNF) protects resistant C57BL/6 mice against herpes simplex virus-induced encephalitis independently of signaling via TNF receptor 1 or 2. J Virol. 2007:81:1451-60.

42. Paludan SR, Ellermann-Eriksen S, Kruys V, Mogensen SC. Expression of TNF-alpha by herpes simplex virus-infected macrophages is regulated by a dual mechanism: transcriptional regulation by NF-kappa B and activating transcription factor $2 / J u n$ and translational regulation through the AU-rich region of the $3^{\prime}$ untranslated region. J Immunol. 2001;167:2202-8.

43. Lokensgard JR, Hu S, Sheng W, van Oijen M, Cox D, Cheeran MC, et al. Robust expression of TNF-alpha, IL-1beta, RANTES, and IP-10 by human microglial cells during nonproductive infection with herpes simplex virus. J Neurovirol. 2001;7:208-19.

44. Ben Hur T, Rosenthal J, Itzik A, Weidenfeld J. Adrenocortical activation by herpes virus: involvement of IL-1 beta and central noradrenergic system. Neuroreport. 1996:7:927-31.

45. Matta H, Chaudhary PM. Activation of alternative NF-kappa B pathway by human herpes virus 8-encoded Fas-associated death domain-like IL-1 beta-converting enzyme inhibitory protein (VFLIP). Proc Natl Acad Sci U S A. 2004;101:9399-404

46. LeBlanc RA, Pesnicak L, Cabral ES, Godleski M, Straus SE. Lack of interleukin-6 (IL-6) enhances susceptibility to infection but does not alter latency or reactivation of herpes simplex virus type 1 in IL-6 knockout mice. J Virol. 1999;73:8145-51

47. Wickham S, Ash J, Lane TE, Carr DJ. Consequences of CXCL10 and IL-6 induction by the murine IFN-alpha1 transgene in ocular herpes simplex virus type 1 infection. Immunol Res. 2004;30:191-200.

48. Obolonczyk L, Siekierska-Hellmann M, Sworczak K. [Side effects during interferon-alpha therapy of hepatitis $C$ with special consideration of thyroid dysfunction]. Postepy Hig Med Dosw (Online). 2008;62:309-21.

49. Sleijfer S, Bannink M, Van Gool AR, Kruit WH, Stoter G. Side effects of interferon-alpha therapy. Pharm World Sci. 2005;27:423-31.

50. La S, Kim E, Kwon B. In vivo ligation of glucocorticoid-induced TNF receptor enhances the T-cell immunity to herpes simplex virus type 1. Exp Mol Med. 2005;37:193-8

51. Morel Y, de Colella JM S, Harrop J, Deen KC, Holmes SD, Wattam TA, et al. Reciprocal expression of the TNF family receptor herpes virus entry mediator and its ligand LIGHT on activated T cells: LIGHT down-regulates its own receptor. J Immunol. 2000;165:4397-404.

52. Jacquemin G, Shirley S, Micheau O. Combining naturally occurring polyphenols with TNF-related apoptosis-inducing ligand: a promising approach to kill resistant cancer cells? Cell Mol Life Sci. 2010;67:3115-30.

53. Antoni C, Braun J. Side effects of anti-TNF therapy: current knowledge. Clin Exp Rheumatol. 2002:20:S152-7.

54. Wei G, Zhang M, Mei Y, Dong J. Expression of cytokines IL-2, IL-10 and TNF-alpha in mice with herpes simplex viral encephalitis. J Huazhong Univ Sci Technolog Med Sci. 2006;26:308-10.

55. Ruby J, Bluethmann H, Peschon JJ. Antiviral activity of tumor necrosis factor (TNF) is mediated via p55 and p75 TNF receptors. J Exp Med. 1997;186:1591-6

56. Bartee E, Mohamed MR, Lopez MC, Baker HV, McFadden G. The addition of tumor necrosis factor plus beta interferon induces a novel synergistic antiviral state against poxviruses in primary human fibroblasts. J Virol. 2009;83:498-511.

57. Fitzgerald KA. Integr-ating IL-1 alpha in antiviral host defenses. Immunity. 2009;31:7-9

58. Schijns VE, Claassen IJ, Vermeulen AA, Horzinek MC, Osterhaus AD. Modulation of antiviral immune responses by exogenous cytokines: effects of tumour necrosis factor-alpha, interleukin-1 alpha, interleukin-2 and interferon-gamma on the immunogenicity of an inactivated rabies vaccine. J Gen Virol. 1994;75:55-63.

59. Kayamuro H, Yoshioka $Y$, Abe $Y$, Arita $S$, Katayama $K$, Nomura $T$, et al. Interleukin-1 Family Cytokines as Mucosal Vaccine Adjuvants for Induction of Protective Immunity against Influenza Virus. J Virol. 2010;84:12703-12.

60. Thompson AJ, Colledge D, Rodgers S, Wilson R, Revill P, Desmond P, et al. Stimulation of the interleukin-1 receptor and Toll-like receptor 2 inhibits hepatitis B virus replication in hepatoma cell lines in vitro. Antivir Ther. 2009:14:797-808.

61. Clarke P, Debiasi RL, Meintzer SM, Robinson BA, Tyler KL. Inhibition of NF-kappa B activity and CFLIP expression contribute to viral-induced apoptosis. Apoptosis. 2005;10:513-24.

62. Unterstab G, Ludwig S, Anton A, Planz O, Dauber B, Krappmann D, et al. Viral targeting of the interferon-\{beta\}-inducing Traf family 
member-associated NF-\{kappa\}B activator (TANK)-binding kinase-1. Proc Natl Acad Sci U S A. 2005;102:13640-5.

63. Stratil P, Klejdus B, Kuban V. Determination of total content of phenolic compounds and their antioxidant activity in vegetables-evaluation of spectrophotometric methods. J Agric Food Chem. 2006;54:607-16.

64. Piazza GA, Rahm AL, Krutzsch M, Sperl G, Paranka NS, Gross PH, et al. Antineoplastic drugs sulindac sulfide and sulfone inhibit cell growth by inducing apoptosis. Cancer Res. 1995:55:3110-6.

65. Cann AJ. Virus culture - a practical approach. 1st ed. USA: Oxford University Press; 1999.

66. Roner MR, Joklik WK. Reovirus reverse genetics: incorporation of the CAT gene into the reovirus genome. Proc Natl Acad Sci U S A. 2001;98:8036-41.

67. Mosmann T. Rapid colorimetric assay for cellular growth and survival: application to proliferation and cytotoxicity assays. J Immunol Methods. 1983;65:55-63.

68. Wyde PR, Ambrose MW, Meyerson LR, Gilbert BE. The antiviral activity of SP-303, a natural polyphenolic polymer, against respiratory syncytial and parainfluenza type 3 viruses in cotton rats. Antiviral Res. 1993;20:145-54.

69. Betancur-Galvis L, Zuluaga C, Arno M, Gonzalez MA, Zaragoza RJ. Structure-activity relationship of in vitro antiviral and cytotoxic activity of semisynthetic analogues of scopadulane diterpenes. J Nat Prod. 2001;64:1318-21.

70. Suzutani T, Ogasawara M, Yoshida I, Azuma M, Knox YM. Anti-herpesvirus activity of an extract of Ribes nigrum L. Phytother Res. 2003;17:609-13.

71. Behbahani M. Anti-viral activity of the methanolic leaf extract of an Iranian medicinal plant "Hyssopus officinalis" against herpes simplex virus. JMPR. 2009;3:1118-25.

72. Li Y, Leung KT, Yao F, Ooi LS, Ooi VE. Antiviral flavans from the leaves of Pithecellobium clypearia. J Nat Prod. 2006;69:833-5.

73. Wang $\mathrm{H}$, Ooi EV, Ang Jr PO. Antiviral activities of extracts from Hong Kong seaweeds. J Zhejiang Univ Sci B. 2008;9:969-76.

74. Chiang LC, Ng LT, Cheng PW, Chiang W, Lin CC. Antiviral activities of extracts and selected pure constituents of Ocimum basilicum. Clin Exp Pharmacol Physiol. 2005;32:811-6

75. Cheng PW, Chiang LC, Yen MH, Lin CC. Bupleurum kaoi inhibits Coxsackie B virus type 1 infection of CCFS-1 cells by induction of type I interferons expression. Food Chem Toxicol. 2007;45:24-31.

76. Wang KC, Chang JS, Chiang LC, Lin CC. 4-Methoxycinnamaldehyde inhibited human respiratory syncytial virus in a human larynx carcinoma cell line. Phytomedicine. 2009;16:882-6.

77. Roner MR, Sprayberry J, Spinks M, Dhanji S. Antiviral activity obtained from aqueous extracts of the Chilean soapbark tree (Quillaja saponaria Molina). J Gen Virol. 2007:88:275-85.

78. Li Y, Jiang R, Ooi LS, But PP, Ooi VE. Antiviral triterpenoids from the medicinal plant Schefflera heptaphylla. Phytother Res. 2007;21:466-70.

79. Rajbhandari M, Wegner U, Julich M, Schopke T, Mentel R. Screening of Nepalese medicinal plants for antiviral activity. J Ethnopharmacol. 2001;74:251-5.

80. Kang JX, Liu J, Wang J, He C, Li FP. The extract of huanglian, a medicinal herb, induces cell growth arrest and apoptosis by upregulation of interferon-beta and TNF-alpha in human breast cancer cells. Carcinogenesis. 2005;26:1934-9.

\section{Submit your next manuscript to BioMed Central and take full advantage of:}

- Convenient online submission

- Thorough peer review

- No space constraints or color figure charges

- Immediate publication on acceptance

- Inclusion in PubMed, CAS, Scopus and Google Scholar

- Research which is freely available for redistribution

Submit your manuscript at www.biomedcentral.com/submit 